OPEN ACCESS

Edited by:

Esther Udina,

Autonomous University of Barcelona,

Spain

Reviewed by:

Doychin N. Angelov,

Medizinische Fakultät, Universität zu

Köln, Germany

Guilherme Lucas,

University of São Paulo, Brazil

*Correspondence:

Claire Emma McGregor

clairekmcgregor@gmail.com

Received: 26 September 2018 Accepted: 14 December 2018

Published: 11 January 2019

Citation:

McGregor CE and English AW (2019)

The Role of BDNF in Peripheral Nerve

Regeneration: Activity-Dependent

Treatments and Val66Met.

Front. Cell. Neurosci. 12:522.

doi: 10.3389/fncel.2018.00522

\section{The Role of BDNF in Peripheral Nerve Regeneration: Activity-Dependent Treatments and Val66Met}

\author{
Claire Emma McGregor* and Arthur W. English \\ Department of Cell Biology, Emory University School of Medicine, Atlanta, GA, United States
}

Despite the ability of peripheral nerves to spontaneously regenerate after injury, recovery is generally very poor. The neurotrophins have emerged as an important modulator of axon regeneration, particularly brain derived neurotrophic factor (BDNF). BDNF regulation and signaling, as well as its role in activity-dependent treatments including electrical stimulation, exercise, and optogenetic stimulation are discussed here. The importance of a single nucleotide polymorphism in the BDNF gene, Val66Met, which is present in $30 \%$ of the human population and may hinder the efficacy of these treatments in enhancing regeneration after injury is considered. Preliminary data are presented on the effectiveness of one such activity-dependent treatment, electrical stimulation, in enhancing axon regeneration in mice expressing the met allele of the Val66Met polymorphism.

Keywords: peripheral nerve injury, BDNF, Val66Met, trkB, electrical stimulation, exercise, optogenetics

\section{PERIPHERAL NERVE INJURY}

Despite the ability of axons in peripheral nerves to regenerate, recovery is generally very poor (Portincasa et al., 2007; Scholz et al., 2009). The cellular changes that occur after an injury often cannot sustain axon regeneration for the duration required to reinnervate target organs (Fu and Gordon, 1995a,b). The neurotrophins have emerged as an important modulator of axon regeneration, particularly brain derived neurotrophic factor (BDNF). Here, we will review BDNF and its role in activity-dependent treatments to enhance regeneration. Then we will discuss a single nucleotide polymorphism in the $b d n f$ gene, Val66Met, which is present in $30 \%$ of the human population and may hinder the efficacy of these treatments (Egan et al., 2003; Shimizu et al., 2004). Finally, we will present preliminary data on the effectiveness of one such activity-dependent treatment, electrical stimulation (ES), in enhancing axon regeneration in mice expressing the met allele of the Val66Met polymorphism.

\section{BRAIN DERIVED NEUROTROPHIC FACTOR}

BDNF is a member of the neurotrophin family, which also includes nerve growth factor (NGF), neurotrophin 3 (NT3), and neurotrophin 4/5 (NT4/5). BDNF is required for normal development-BDNF knockout (KO) is embryonic lethal (Jones et al., 1994; Schwartz et al., 1997). In adulthood, BDNF is involved in synaptic plasticity, long term potentiation (LTP), learning and memory as well as hippocampal neurogenesis and regeneration after injury (Lindsay, 1988; Lewin and Barde, 1996; Lu et al., 2014; Richner et al., 2014). In the subsequent paragraphs, we review 
how BDNF is regulated at the level of mRNA transcripts, protein trafficking, and receptor binding, following with its role in peripheral nerve regeneration.

\section{Regulation of BDNF Transcripts}

The human BDNF gene resides on the short arm of the 11th chromosome (Maisonpierre et al., 1991). It consists of 9 exons-eight $5^{\prime}$ untranslated exons and one protein coding $3^{\prime}$ exon (Figure 1) (Liu et al., 2006; Aid et al., 2007; Pruunsild et al., 2007). Through alternative splicing, 17 distinct mRNA transcripts for BDNF have been identified in humans and 11 in rodents (Pruunsild et al., 2007). Additionally, the $3^{\prime} \mathrm{UTR}$ of the gene contains two polyadenylation sites, resulting in both a long $3^{\prime} \mathrm{UTR}$ and a short $3^{\prime} \mathrm{UTR}$, doubling the possible splice variants. The entire protein-coding region resides on exon IX, so the mature BDNF protein synthesized is identical regardless of mRNA splicing. Splice variants allow for spatial and temporal control of the BDNF transcript.

Spatial control of the $5^{\prime}$ UTRs can be seen in exon expression throughout the body. BDNF transcripts containing exons I, II, and III are found exclusively in the brain, and transcripts containing exon IV are predominantly found peripherally in the lung and heart, but can also be found in brain tissue (Timmusk et al., 1993). Even within brain tissue, different promoters can be found in different cell types. For example, exon IV transcripts are required for proper GABAergic interneuron function in the prefrontal cortex (Sakata et al., 2009).

Many different stimuli exert temporal control over BDNF transcription. In cultured cortical neurons, $\mathrm{Ca}^{2+}$ influx results predominantly in transcription of exon IV-containing mRNA (Tao et al., 1998). This promoter contains a cAMP/Ca ${ }^{2+}$ response element-like element (CaRE3/CRE) that is required for activity-dependent transcription (Tao et al., 1998; Hong et al., 2008). The transcription factor CREB binds this element, is phosphorylated by calcium-regulated kinase cascades, and recruits transcriptional machinery resulting in $\mathrm{Ca}^{2+}$ dependent transcription of exon IV-containing BDNF mRNA (West et al., 2001; Lonze and Ginty, 2002). Other stimuli have been identified in modulating BDNF expression. In motoneurons, exon VI transcripts are androgen sensitive, despite no known androgen response element on the $b d n f$ gene (Ottem et al., 2010; Sabatier and English, 2015). There is, however, an estrogen response element (Sohrabji et al., 1995). SRY-box containing gene 11 (Sox11), a transcription factor involved in neuronal survival, axon growth, and regeneration after injury, increases exon I containing BDNF mRNA transcripts specifically in peripheral DRG neurons, but not in CNS neurons (Jankowski et al., 2006; Salerno et al., 2012; Struebing et al., 2017). Exons II and VI are sensitive to tricyclic and atypical antidepressants (Vaghi et al., 2014).

A further role for $5^{\prime}$ promoter exons regulating BDNF mRNA may lie in mRNA trafficking. In both cortical and hippocampal neurons, BDNF mRNA is found in dendrites and activity induces trafficking of BDNF mRNA to distal dendrites (Tongiorgi et al., 1997; Capsoni et al., 1999; Chiaruttini et al., 2008, 2009). Interestingly, only certain splice variants are found in dendritesthose containing exons IIB, IIC, and VI (Pattabiraman et al., 2005; Chiaruttini et al., 2008). Transcripts containing exons I, III, and IV are restricted to the cell body.

Further spatial and temporal translational control of BDNF mRNA may come via the $3^{\prime}$ UTR. The $b d n f 3^{\prime}$ UTR contains two polyadenylation sites. This allows for both a long $3^{\prime}$ UTR and a short 3'UTR to be transcribed (Timmusk et al., 1993; Aid et al., 2007; Pruunsild et al., 2007). These different $3^{\prime}$ UTRs are thought to determine mRNA trafficking within the cell. Both the long and short 3'UTR transcripts can be found in the dendrites under different conditions (Vicario et al., 2015). However, in general, the long $3^{\prime}$ UTR transcripts are trafficked to the dendrites, where local BDNF synthesis can regulate pruning and enlargement of synapses, whereas the short $3^{\prime}$ UTR transcripts stay in the cell body (An et al., 2008). Both depolarization of the neuron as well as BDNF itself increase the number of BDNF mRNA transcripts targeted to the dendrites (Tongiorgi et al., 1997; Righi et al., 2000). Remarkably, the short $3^{\prime}$ UTR transcripts account for the majority of BDNF translation, whereas the long 3'UTR transcripts are translationally repressed by RNA binding proteins which stabilize the mRNA until neural activity elicits rapid local translation (Lau et al., 2010; Allen et al., 2013; Vaghi et al., 2014). Calcium influx associated with neuronal activity

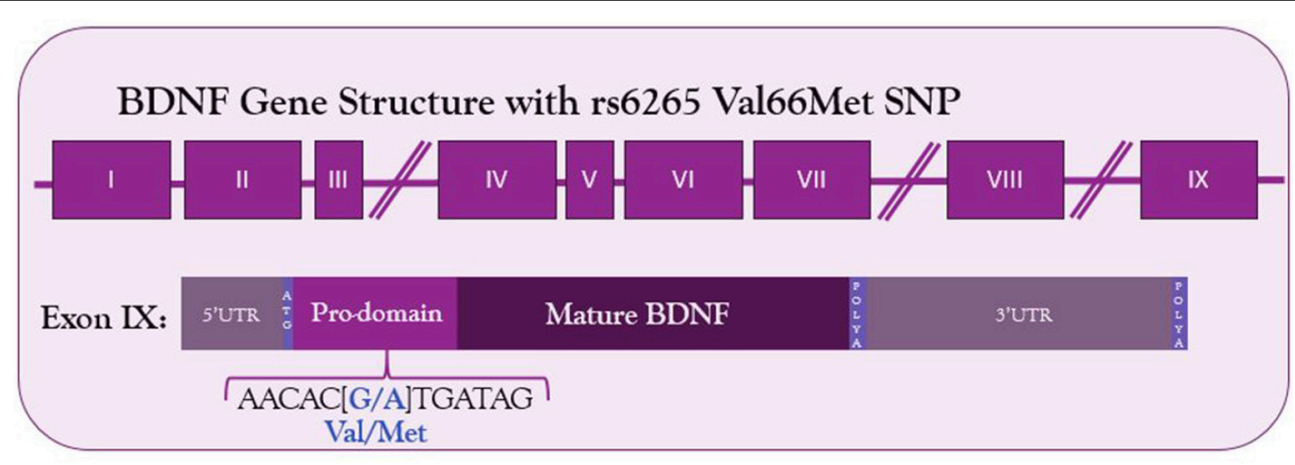

FIGURE 1 | Structure of BDNF gene and location of Val66Met SNP in the coding exon IX. The G to A substitution in the prodomain results in a valine to methionine substitution and decreased $\mathrm{Ca}^{2+}$-dependent release of BDNF. 
also results in increased stabilization of BDNF mRNA (Fukuchi and Tsuda, 2010). Conversely, the $3^{\prime}$ UTR also contains regions which interact with microRNAs, which are short, non-coding RNA strands that complement mRNA transcripts and result in transcript degradation (Bartel, 2004). Numerous microRNAs have been identified as regulators of BDNF, and microRNA access to binding sites depends on the presence of the long or short 3'UTR (Mellios et al., 2008; Varendi et al., 2014).

\section{BDNF Trafficking and Secretion}

BDNF, like the other neurotrophins, is synthesized as a preproprotein. The pre-domain functions as a signaling peptide that directs synthesis to the endoplasmic reticulum (ER) for future packaging as a secretory protein. It is immediately cleaved to form proBDNF upon sequestration in the ER (Lessmann et al., 2003). Within the ER, proBDNF forms homodimers (Kolbeck et al., 1994). Both proBDNF and a further cleaved form, mature BDNF, can be packaged into vesicles and secreted. ProBDNF is approximately $29 \mathrm{kDa}$, and once cleaved, mature BDNF is approximately $14 \mathrm{kDa}$ (Seidah et al., 1996a). Intracellularly, cleavage can occur within the trans-Golgi network or secretory vesicles by furin, a protease, and proprotein convertases PCSK6 and PC5-6b. Extracellularly, cleavage is executed by tissue plasminogen activator or matrix metalloproteinases, which are secreted in an activity-dependent manner (Krystosek and Seeds, 1981; Gualandris et al., 1996; Seidah et al., 1996a,b; Lee et al., 2001; Mowla et al., 2001; Hwang et al., 2005; Keifer et al., 2009; Nagappan et al., 2009; Yang et al., 2009). Once cleaved, the prodomain is not immediately degraded, and can be secreted with mature BDNF (Anastasia et al., 2013).

From the trans-Golgi network, BDNF is directed to two different secretory pathways: a constitutive pathway and a regulated, $\mathrm{Ca}^{2+}$ dependent pathway (Mowla et al., 1999; Lessmann et al., 2003; Kuczewski et al., 2009). The constitutive pathway consists of small granules $(50-100 \mathrm{~nm}$ diameter) that fuse with the cell membrane near the neuronal somata and proximal processes. The regulated secretory pathway consists of larger granules $(300 \mathrm{~nm}$ diameter) that fuse in distal processes and axon terminals (Conner et al., 1997; Kohara et al., 2001; Brigadski et al., 2005; Dieni et al., 2012). The dual pathway for release is distinctive of BDNF. The other neurotrophins are preferentially secreted through a constitutive pathway. Under normal conditions, most neuronal BDNF is packaged into the regulated pathway (Lu et al., 2014).

Two important interactions have been identified in the sorting of BDNF into the regulatory pathway. The first to be discovered was the interaction between the sorting receptor carboxipeptidase $\mathrm{E}$ (CPE) and a three-dimensional motif on the mature domain of BDNF (Lou et al., 2005). Knocking out CPE in cortical neurons blocks activity-dependent release of $\mathrm{BDNF}$ and increases constitutive release. Similarly, adding this motif to NGF redirected its release to the regulated secretory pathway (Lou et al., 2005). The second interaction is between the prodomain and the protein sortilin (Chen et al., 2005). Sortilin is localized predominantly to the Golgi apparatus and interacts with the BDNF prodomain to direct it to the regulated secretory pathway (Nielsen et al., 2001; Chen et al., 2005). When sortilin is unable to interact with the prodomain of BDNF, regulated release is decreased, but there is no compensatory increase in constitutive release (Chen et al., 2005; Lu et al., 2005). This has led to the hypothesis that the interaction between sortilin and the prodomain of BDNF is necessary for proper protein folding, which allows CPE to interact with the mature domain and sort BDNF into one of the two pathways (Lu et al., 2005). When NT-4/5, which is secreted constitutively, is modified to contain the BDNF prodomain, it is trafficked to the regulated secretory pathway (Brigadski et al., 2005). Similarly, blocking the cleavage of the prodomain of NGF, which is also released constitutively, results in its sorting into regulated secretory pathways (Mowla et al., 1999).

\section{BDNF Receptors}

Once secreted, BDNF can bind to one of two receptorstropomyosin receptor kinase $\mathrm{B}$ (trkB) or the common neurotrophin receptor, $\mathrm{p} 75^{\mathrm{NTR}}$. Mature BDNF preferentially binds trkB, resulting in pro-growth signaling, whereas proBDNF (as well as the other proneurotrophins) preferentially binds p $75^{\mathrm{NTR}}$, resulting in antigrowth signaling (Lee et al., 2001). BDNF is primarily secreted as proBDNF (Mowla et al., 1999, 2001; Chen et al., 2004). Thus the availability of proteins that cleave the prodomain may regulate which receptor is activated by BDNF release, providing another mechanism for control of BDNF signaling.

The trkB receptor is a typical tyrosine kinase. When ligand is bound, it dimerizes and autophosphorylates. In addition to BDNF, trkB can also bind NT-4/5. Several isoforms of trkB have been discovered, including isoforms that change its sensitivity to NT-4/5, as well as a truncated form that lacks an intracellular kinase domain (Eide et al., 1996). The truncated form acts as a dominant negative receptor, forming heterodimers with full length trkB receptors and blocking neurotrophin signaling (Eide et al., 1996; Fryer et al., 1997). Another possible role for truncated trkB on astrocytes and Schwann cells may be to act to control the pool of available neurotrophins, preventing them from degrading or signaling until released into the extracellular space (Alderson et al., 2000). In its fulllength form, trkB has several intracellular tyrosine residues that can be phosphorylated (Huang and Reichardt, 2003). Three possible signaling cascades are then activated: phospholipase $\mathrm{C}$ gamma (PLCy); phosphotidyl-inositol-3 kinase (PI3K); and mitogen activated protein kinase/extracellular receptor kinase (MAPK/ERK) (Reichardt, 2006).

The phosphorylation of residue Y490 creates a binding site for adaptor protein Shc (Patapoutian and Reichardt, 2001). Shc binding trkB allows for activation of Ras and further activation of the MAPK/ERK pathway. Downstream of this pathway is mechanistic target of rapamycin (mTOR). Shc binding residue Y490 also results in the recruitment of PI3K and activation of protein kinase B (Akt) (Reichardt, 2006). The phosphorylation of residue Y785 creates a binding site for PLCy, which is then phosphorylated by trkB (Patapoutian and Reichardt, 2001). This phosphorylation activates PLCy, which then hydrolizes phosphotidylinositides to generate diacylglyerol (DAG), which activates protein kinase $\mathrm{C}(\mathrm{PKC})$, and inositol 1,4,5 triphosphate 
$\left(\mathrm{IP}_{3}\right)$, which results in an influx of intracellular $\mathrm{Ca} 2+$ stores from the ER. These signaling cascades all converge at the level of the nucleus, where transcription is affected through CREB and other transcription factors (Minichiello, 2009).

Once bound to ligand, trkB is endocytosed to form a signaling endosome (Delcroix et al., 2003; Reichardt, 2006). Both ligand and receptor are contained within the endosome, allowing trkB to continue signaling as it is trafficked through the cell. In this way, trkB can be moved closer to the nucleus, where it can affect gene transcription, as well as brought into closer proximity to signaling effectors (Delcroix et al., 2003). However, not all actions of trkB happen at the level of the soma-BDNF-trkB activation has been shown to affect local protein synthesis in the growth cone as well (Yao et al., 2006).

The second receptor for BDNF is the pan-neurotrophin receptor, p $75^{\mathrm{NTR}}$ (Rodríguez-Tébar et al., 1992). Generally thought of as a pro-death receptor, $\mathrm{p} 75^{\mathrm{NTR}}$ is a member of the tumor necrosis factor receptor super family and contains a cytosolic death domain (Liepinsh et al., 1997; Locksley et al., 2001). It is expressed primarily during development, but sensory neurons and spinal motoneurons maintain low expression through adulthood (Ernfors et al., 1989; Heuer et al., 1990; Wyatt et al., 1990; Ibáñez and Simi, 2012). Its cytosolic domain is nonenzymatic, so its actions depend entirely on associations with cytoplasmic proteins (Nagata, 1997). Despite its canonical role, $\mathrm{p} 75^{\mathrm{NTR}}$ can mediate both pro-death and pro-survival signals depending on its cytosolic partners. For example, p $75^{\mathrm{NTR}}$ is required during development for normal neuron growth and ramification (Yamashita et al., 1999). Multiple adaptor complexes interact with its cytosolic domain to mediate downstream effects (Dechant and Barde, 2002).

Additionally, $\mathrm{p} 75^{\mathrm{NTR}}$ has multiple membrane-bound and extracellular binding partners which can alter whether its signaling is pro-survival or pro-death. Through extracellular pairing with sortilin, $\mathrm{p} 75^{\mathrm{NTR}}$ is able to bind the proneurotrophins (Nykjaer et al., 2004; Teng et al., 2005), resulting in pro-death or anti-growth signaling through downstream JNK activation or caspase activation (Reichardt, 2006). However, neurotrophin binding to $75^{\mathrm{NTR}}$ can also result in NFKB activity, which is a pro-survival signal (Carter et al., 1996; Hamanoue et al., 1999; Middleton et al., 2000). One key protein regulated by $\mathrm{p} 75^{\mathrm{NTR}}$ is RhoA, a small GTPase that regulates the actin cytoskeleton and inhibits axon elongation (Walsh et al., 1999; Schmidt and Hall, 2002). Through such interactions with the socalled death domain of $\mathrm{p} 75^{\mathrm{NTR}}$, neurotrophin binding inhibits Rho (Yamashita et al., 1999; Roux and Barker, 2002). Through forming a receptor complex with the Nogo receptor, NgR1, p $75^{\mathrm{NTR}}$ can act as a receptor for myelin-associated glycoprotein (MAG) (Wang et al., 2002), which enhances Rho activation and results in neurite collapse (Mi et al., 2004). Curiously, p $75^{\mathrm{NTR}}$ can act as a binding partner for the trks, including trkB, and increases affinity and selectivity of binding and thus enhancing trk signaling (Bibel et al., 1999).

Like trkB, truncated forms of $\mathrm{p} 75^{\mathrm{NTR}}$ have been identified. One short $\mathrm{p} 75^{\mathrm{NTR}}$ isoform lacks an extracellular ligand binding domain, but contains its intracellular machinery (Roux and Barker, 2002). This form is unable to bind the neurotrophins
(Dechant and Barde, 1997). The extracellular domain of $\mathrm{p} 75^{\mathrm{NTR}}$ can also be cleaved by extracellular metalloproteinases (Roux and Barker, 2002). These isoforms could act as modulators of neurotrophin signaling.

The two receptors for BDNF are generally thought to have opposing roles and may mediate a balance between growth and death. $\operatorname{trkB}$ has a higher affinity for mBDNF, but as levels of neurotrophin increase, $\mathrm{p} 75^{\mathrm{NTR}}$ will also bind $\mathrm{mBDNF}$ and activate signals in direct opposition to trkB. Because of the different affinities for pro- and mature BDNF, cleavage of BDNF becomes another mechanism to control its downstream signaling effects (Lee et al., 2001). Depolarization of a neuron, which results in secretion of BDNF, also results in secretion of tissue plasminogen activator which cleaves proBDNF to create mature BDNF (Gualandris et al., 1996). BDNF-trkB signaling increases expression of matrix metalloproteinase 9, which also cleaves BDNF (Kuzniewska et al., 2013).

\section{ROLE OF BDNF IN PERIPHERAL NERVE INJURY}

In peripheral nerves, BDNF is synthesized by motoneurons, a subset of DRG neurons, and Schwann cells (Apfel et al., 1996; Cho et al., 1997; Michael et al., 1997). After nerve crush or complete transection, BDNF mRNA increases in all three cell types, including in trkB- and trkC-expressing DRG neurons not found previously to express BDNF (Meyer et al., 1992; Funakoshi et al., 1993; Kobayashi et al., 1996; Michael et al., 1999; Al Majed et al., 2000a; English et al., 2007). BDNF mRNA can be found in low levels in the sciatic nerve, and after injury, that expression is upregulated. This upregulation is sustained over the course of weeks and can be attributed to both neuronal and non-neuronal sources (Meyer et al., 1992; Funakoshi et al., 1993). In facial nerve injury, upregulation of BDNF is correlated with enhanced functional outcome (Grosheva et al., 2016).

Following sciatic nerve injury, a transient increase in both BDNF and full length trkB mRNA is found in motoneurons (Kobayashi et al., 1996; Al Majed et al., 2000a). Unlike sensory neurons, NGF and trkA are not expressed by motoneurons, nor are they upregulated after injury (Funakoshi et al., 1993; Escandon et al., 1994). There is a small and short-lived upregulation of NT3 and NT4/5 in motoneurons (Funakoshi et al., 1993). TrkC is expressed by adult motoneurons, but it is not upregulated after injury (Johnson et al., 1999). Thus, the rapid upregulation of BDNF and trkB make it likely that BDNF is the main neurotrophin mediating early motoneuron response to nerve injury (Boyd and Gordon, 2003).

Schwann cells express only the truncated form of trkB, which has the potential to act as a dominant negative receptor for BDNF and NT4/5. Schwann cell truncated trkB mRNA levels decrease significantly after sciatic nerve injury (Frisén et al., 1993). This could be viewed as pro-regenerative, enabling available BDNF to bind to trkB receptors on regenerating neurites and enhance their growth. Conversely, after injury, Schwann cells upregulate $\mathrm{p} 75^{\mathrm{NTR}}$, which has been suggested to result in sequestration of 
neurotrophins and inhibit regeneration (Taniuchi et al., 1986; Bibel et al., 1999; Scott and Ramer, 2010).

\section{trkB in Peripheral Nerve Injury}

Axons regenerate through the formation of growth cones, which need cytoskeletal proteins, such as actin and tubulin, to extend and stabilize the new growth. Beta actin mRNA is localized to peripheral axons, and peripheral nerve injury triggers actin mRNA to be transported down the axon for local protein synthesis (Koenig et al., 2000; Sotelo-Silveira et al., 2008; Willis et al., 2011). BDNF/trkB signaling triggers local translation of transported mRNAs through a $\mathrm{Ca}^{2+}$-dependent mechanism, and this is required for bidirectional turning toward BDNF (Yao et al., 2006). BDNF application to injured axons increases the number of actin waves (transport of actin filaments and associated proteins toward the growth cone) per hour (Difato et al., 2011; Inagaki and Katsuno, 2017). Neurotrophins also stimulate growth cone sprouting and actin accumulation in the sprouts (Gallo and Letourneau, 1998). Both of these processes are mediated through the PIP3/PI3K signaling pathway described above (Asano et al., 2008). When an actin wave reaches the growth cone, the growth cone enlarges, branches, and undergoes forward expansion (Flynn et al., 2009). Application of BDNF to growth cones results in microtubule reorganization to form lamellipodial as well as filopodial elongation (Gibney and Zheng, 2003).

In addition to local protein synthesis, trkB signaling has effects on cyclic AMP (cAMP) production, which may be important for the initial extension of growth cones across the site of injury. The MAPK/ERK pathway of BDNF/trkB signaling results in inhibition of phosphodiesterases (PDE) which normally degrade cAMP (Gao et al., 2003). As such, BDNF/trkB signaling results in increased levels of cAMP (Souness et al., 2000; Gao et al., 2003). This pathway has been shown to be necessary to overcome inhibition by MAG, and therefore PDE inhibition has been most thoroughly studied in models of spinal cord injury, where MAG inhibition of axon growth creates a substantial barrier to regeneration (Cai et al., 1999; Gao et al., 2003; Batty et al., 2017). Although injured peripheral nerves do not suffer inhibition by MAG to the same extent as that seen in the central nervous system, early in the regeneration process, inhibitory proteoglycans and myelin debris form an impermissible environment for axon regeneration (shen et al., 1998). Increasing cAMP through PDE inhibition enhances peripheral regeneration after injury, and it is likely that trkB activation contributes to this cAMP-mediated effect on regeneration (Gordon et al., 2009; Udina et al., 2010).

The different neurotrophin signaling pathways activated through trk receptors converge at the level of transcription in the nucleus. CREB, resulting from trkB-generated PI3KAkt activation, increases sensory neurite outgrowth (White et al., 2000). Inhibiting phosphatase and tensin homolog (PTEN), an endogenous inhibitor of the PI3K pathway, through genetic knock out or pharmacology, enhances peripheral nerve regeneration in vivo and neurite outgrowth in vitro (Park et al., 2008; Christie et al., 2010). Numerous other transcription factors downstream of MAPK/ERK signaling, such as c-jun, STAT3, and
ATF-3, have all been associated with changes in gene expression after injury that enhance survival and regeneration (Makwana and Raivich, 2005). mTOR, also downstream of MAPK/ERK signaling and repressed by PTEN, regulates protein synthesis and is also beneficial for DRG regeneration after injury (Park et al., 2008; Abe et al., 2010).

\section{p75 ${ }^{\text {NTR }}$ in Peripheral Nerve Injury}

Because of its roles in both pro-death and pro-survival signaling, it is not surprising that the role of $\mathrm{p} 75^{\mathrm{NTR}}$ in regeneration after injury has been controversial. Although generally considered an anti-growth signal, its role is far more complex as evidenced by conflicting results using $\mathrm{p} 75^{\mathrm{NTR}}$ knock-out mice.

Although expression is high during development, mature Schwann cells do not express $\mathrm{p} 75^{\mathrm{NTR}}$. Schwann cell expression of p $75^{\mathrm{NTR}}$ increases after injury (Taniuchi et al., 1986; Heumann et al., 1987a,b). Deletion of p75 ${ }^{\mathrm{NTR}}$ in Schwann cells mediates improved regeneration in DRG neurons (Scott and Ramer, 2010). Conversely, for motoneurons, Schwann cell $\mathrm{p} 75^{\mathrm{NTR}}$ deletion results in diminished functional recovery and axonal growth (Tomita et al., 2007). Expression of p $75^{\text {NTR }}$ is thought to mediate remyelination through a BDNF-dependent mechanism. Disruption of endogenous BDNF signaling impairs myelination (Cosgaya et al., 2002; Zhang et al., 2008), as does p75 knockout from Schwann cells (Cosgaya et al., 2002; Song et al., 2006; Tomita et al., 2007).

In motoneurons, $\mathrm{p} 75^{\mathrm{NTR}}$ levels rise dramatically after injury, returning to baseline levels by 30 days (Raivich and Kreutzberg, 1987; Yan and Johnson, 1988; Ernfors et al., 1989; Koliatsos et al., 1991; Saika et al., 1991; Rende et al., 1995; Gschwendtner et al., 2003). This upregulation in $\mathrm{p} 75^{\mathrm{NTR}}$ does not result in motoneuron cell death, however (Bueker and Meyers, 1951; Kuzis et al., 1999). Treating injured motoneurons with lowlevels of recombinant human BDNF enhances their regeneration. Higher doses, however, result in failure to regenerate, which can be reversed by p $75^{\text {NTR }}$ blockade (Boyd and Gordon, 2002). There is currently no motoneuron-specific p $75^{\text {NTR }}$ knockout model, but conflicting results have been found with regard to motoneuron regeneration in $\mathrm{p} 75^{\mathrm{NTR}}$ pan-knockout mice. Boyd and Gordon found improved motor axon regeneration in knockout mice after peroneal nerve transection (Boyd and Gordon, 2001). Gschwendtner et al. found no effect of knocking out $\mathrm{p} 75^{\mathrm{NTR}}$ on facial nerve axon regeneration (Gschwendtner et al., 2003). Ferri et al. found worse axon regeneration but improved functional recovery after facial nerve crush (Ferri et al., 1998). Song et al. found fewer regenerating axons in $\mathrm{p} 75^{\mathrm{NTR}}$ knockout mice using both sciatic nerve and facial nerve crush injuries (Song et al., 2009). Most recently, Zhang et al. found worse axonal regeneration among $\mathrm{p} 75^{\mathrm{NTR}}$ knockout mice using a facial nerve crush model (Zhang et al., 2010). Using cell-type specific knockout of $\mathrm{p} 75^{\mathrm{NTR}}$ or targeting the binding partners of $\mathrm{p} 75^{\mathrm{NTR}}$ that result in different signaling could provide clarity to these conflicting results in how $\mathrm{p} 75^{\mathrm{NTR}}$ is affecting motoneuron regeneration.

Sensory neurons decrease expression of $\mathrm{p} 75^{\mathrm{NTR}}$ after injury (Zhou et al., 1996). Unlike adult motoneurons, there is significant cell death of DRG neurons after an injury, but this is restricted 
to small-diameter, mainly cutaneous afferent neurons (Welin et al., 2008; Wiberg et al., 2018). Cell death in these smaller DRG neurons can be blocked by application of NGF (Rich et al., 1987; Ljungberg et al., 1999). Likewise, in injured DRG neurons, BDNF acts in an autocrine loop to prevent cell death, and disruption in BDNF expression increases cell death (Acheson et al., 1995). A decrease in expression of $\mathrm{p} 75^{\mathrm{NTR}}$ could act as a survival signal, such that the endogenous increased neurotrophin secretion would be more likely to bind trk receptors and result in pro-survival signaling. In support of this hypothesis, in cultures of DRG neurons in which p $75^{\mathrm{NTR}}$ has been rendered inactive, cell survival is higher, and increased neurotrophin concentration does not result in increased cell death (Zhou et al., 2005). Similarly, disrupting the NT binding domain of $\mathrm{p} 75^{\mathrm{NTR}}$ results in increased sprouting after injury in DRG neurons (Scott et al., 2005).

Despite the upregulation of BDNF and its receptors after injury, neither BDNF nor the other neurotrophins (NGF, NT3, and NT4/5), is required for spontaneous regeneration of peripheral neurons (Diamond et al., 1987, 1992; Streppel et al., 2002; Wilhelm et al., 2012). However, application of exogenous BDNF enhances axonal regeneration, functional recovery and decreases synaptic stripping (Lewin et al., 1997; Boyd and Gordon, 2002, 2003; Davis-Lopez de Carrizosa et al., 2009). Recently, small molecule trkB agonists have been developed, and these also enhance regeneration after injury (English et al., 2013).

\section{ACTIVITY DEPENDENT TREATMENTS ENHANCE REGENERATION}

The first published report using activity-dependent treatments to enhance peripheral nerve regeneration was from Hines in 1942. He tested both electrical stimulation (ES) and different exercise paradigms in enhancing functional outcome in rats with tibial nerve transections (Hines, 1942). Since then, there has been great interest in treatments which activate injured neurons, collectively known as activity-dependent treatments, to enhance nerve regeneration (Udina et al., 2011a). These treatments include ES (Table 1), exercise (Tables 2-4), and more recently, optogenetic stimulation (Table 5). One benefit of activity-dependent treatments is the potential for easy translation from bench to bedside-using ES and exercise in human patients would require meeting far fewer regulatory requirements than the use of an experimental drug. Moreover, for nerve injuries that require surgical intervention, ES could be performed easily at the time of surgical repair of the nerve, as has already begun with clinical trials for patients undergoing surgery for carpal tunnel release and complete digital nerve transection (Gordon et al., 2010; Wong et al., 2015). Exercise has the advantage of being low cost and allowing patients to take control of their recovery. However, in the case of extensive injuries, exercise may not be an option for a recovering patient. For this reason, finding treatments that mimic the effects of exercise, such as optogenetic stimulation, may be advantageous in treating patients. To accomplish such a goal, an understanding of the biological basis for the enhancement seen with these treatments is necessary.

\section{Electrical Stimulation}

Immediately after a peripheral nerve injury, a calcium wave propagates along the cut axons toward their cell bodies. Blocking this calcium wave through inhibition of voltage gated calcium channels or inhibition of calcium release from the neuronal endoplasmic reticulum blocks regeneration (Ghosh-Roy et al., 2010). It has been proposed that ES mimics the retrograde calcium wave that propagates at the time of injury in order to elicit cell-autonomous mechanisms that initiate regeneration (Mar et al., 2014). This hypothesis is supported by evidence that ES enhances early regeneration by accelerating the process of axons crossing the site of injury to enter endoneurial tubes in the segment of the nerve distal to the injury (Brushart et al., 2002). ES results in a doubling of the number of motoneurons crossing the site of injury into the distal nerve at 1 week after nerve injury (Brushart et al., 2002). Without treatment, axons can take as long as 4 weeks to cross the site of injury, but by 3 weeks after injury, Al Majed et al. found all electrically stimulated motoneurons had already regenerated to their target muscle compared to 8 weeks for untreated controls (Al Majed et al., 2000b; Brushart et al., 2002).

The first applications of ES focused on the functional recovery of the affected muscles. In 1983; Nix and Hopf described that as early as 2 weeks after injury, treatment with $4 \mathrm{~Hz}$ stimulation $24 \mathrm{~h}$ daily increased twitch force, tetanic tension, and muscle action potentials (Nix and Hopf, 1983). In 1985; Pockett and Gavin found earlier return of the plantar extensor reflex with just 15-60 min of $20 \mathrm{~Hz}$ stimulation (Pockett and Gavin, 1985). $\mathrm{Al}$ Majed et al. chose their $20 \mathrm{~Hz}$ regimen based on the mean physiological frequency of motoneuron discharge and tried numerous stimulation regimens, stimulating continuously for $1 \mathrm{~h}, 1$ day, 1 week, and 2 weeks. They were the first to examine the effect of ES on the regenerating axons (Loeb et al., 1987; Al Majed et al., 2000b). Just $1 \mathrm{~h}$ of $20 \mathrm{~Hz}$ stimulation resulted in longlasting enhancement of peripheral nerve regeneration. Following publication of this paper, $20 \mathrm{~Hz}$ stimulation became the standard for studying ES (Table 1).

Without treatment, axon regeneration into motor or sensory pathways in the distal segment of a cut nerve is random for the first 2 weeks following injury (Brushart, 1993). Motoneurons whose axons have entered only sensory pathways (endoneurial tubes previously occupied by cutaneous axons) remain permanently mistargeted (Brushart, 1993). Enhancing the speed of regeneration but increasing mistargeting could result in poorer functional recovery. However, ES has been shown to increase the sensorimotor specificity of regenerating axons after peripheral nerve injury. More motoneurons regenerate exclusively into motor pathways in rats treated with ES (Al Majed et al., 2000b). Fewer than $40 \%$ of injured DRG neurons reinnervated sensory pathways in controls compared to $75 \%$ in ES-treated animals (Brushart et al., 2005). However, innervating a motor endoneurial tube does not necessitate reaching the appropriate muscle target. Indeed, topographic analysis of motoneuron regeneration after ES revealed increased 
TABLE 1 | Effect of electrical stimulation on peripheral nerve regeneration.

\begin{tabular}{|c|c|c|c|c|}
\hline Regimen & & Model & Result & References \\
\hline Unspecified & $3 \mathrm{~min} /$ day & Rat tibial nerve crush & Functional recovery & Hines, 1942 \\
\hline $20 \mathrm{hz}$ & $15-60 \mathrm{~min}$ & Rat sciatic nerve crush & Functional recovery & Pockett and Gavin, 1985 \\
\hline $20 \mathrm{~Hz}$ & $\begin{array}{l}60 \mathrm{~min}, 24 \mathrm{~h}, 1 \\
\text { week, } 2 \text { weeks }\end{array}$ & Rat femoral nerve transection & Axonal growth & Al Majed et al., 2000b \\
\hline $20 \mathrm{~Hz}$ & $8 \mathrm{~h} /$ day $/ 4$ weeks & Rat sciatic nerve avulsion & Functional Recovery & Tam et al., 2001 \\
\hline $100 \mathrm{hz}$ & 10 pulses/2 min & Cultured rat retinal ganglion cell & Neurite outgrowth & Goldberg et al., 2002 \\
\hline $20 \mathrm{~Hz}$ & $1 \mathrm{~h}$ & Rat femoral nerve transection & Axonal growth & Brushart et al., 2002 \\
\hline $20 \mathrm{~Hz}$ & $1 \mathrm{~h}$ & Rat femoral nerve transection & Axonal growth & Brushart et al., 2005 \\
\hline $20 \mathrm{~Hz}$ & $1 \mathrm{~h}$ & Mouse femoral nerve transection & Functional recovery & Ahlborn et al., 2007 \\
\hline$?$ & $\begin{array}{l}30 \mathrm{~min} / \text { day until } \\
\text { recovery }\end{array}$ & Rat facial nerve transection & Functional recovery & Lal et al., 2008 \\
\hline $20 \mathrm{~Hz}$ & $1 \mathrm{~h}$ & Rat sciatic nerve transection & $\begin{array}{l}\text { Functional Recovery Axonal } \\
\text { growth }\end{array}$ & Vivo et al., 2008 \\
\hline $20 \mathrm{hz}$ & $1 \mathrm{~h}$ & $\begin{array}{l}\text { Human carpal tunnel syndrome } \\
\text { release surgery }\end{array}$ & Functional recovery & Gordon et al., 2010 \\
\hline $20 \mathrm{~Hz}$ & 3 days & Rat adult cultured DRG neurons & Neurite outgrowth & Enes et al., 2010 \\
\hline $20 \mathrm{~Hz}$ & $20 \mathrm{~min}$ & $\begin{array}{l}\text { Rat sciatic nerve } \\
\text { Delayed repair } 2 \mathrm{~h}-24 \text { weeks }\end{array}$ & $\begin{array}{l}\text { Axonal growth Functional } \\
\text { recovery }\end{array}$ & Huang et al., 2013 \\
\hline $20 \mathrm{~Hz}$ & $1 \mathrm{~h}$ & Human digital nerve transection & Functional sensory recovery & Wong et al., 2015 \\
\hline $20 \mathrm{~Hz}$ & $1 \mathrm{~h}$ & $\begin{array}{l}\text { Rat common peroneal nerve } \\
\text { transection } \\
\text { Delayed repair } 3 \text { months }\end{array}$ & Axonal growth & Elzinga et al., 2015 \\
\hline
\end{tabular}

misdirection of regenerating motor axons to functionally inappropriate targets by over 500\% (English, 2005). This misdirection resulted in motoneurons previously innervating extensor muscles reinnervating antagonistic flexor muscles.

Appropriate pathway innervation may rely on Schwann cells secreting specific growth factors for motor and sensory tubes. Schwann cells in the cutaneous nerves express high levels of NGF after injury, whereas Schwann cells in ventral roots express high levels of glial cell line-derived neurotrophic factor (GDNF) (Hoke et al., 2006; Brushart et al., 2013). This difference in growth factor expression has been proposed to be the mechanism through which preferential motor reinnervation occurs, with DRG neurons choosing paths with high NGF, and motoneurons entering paths with high GDNF. With no treatment, in rodents, neurotrophin expression peaks 15 days after injury and declines back to baseline by day 30 . The day 15 peak coincides with the 
TABLE 2 | Effects of treadmill training on peripheral nerve regeneration.

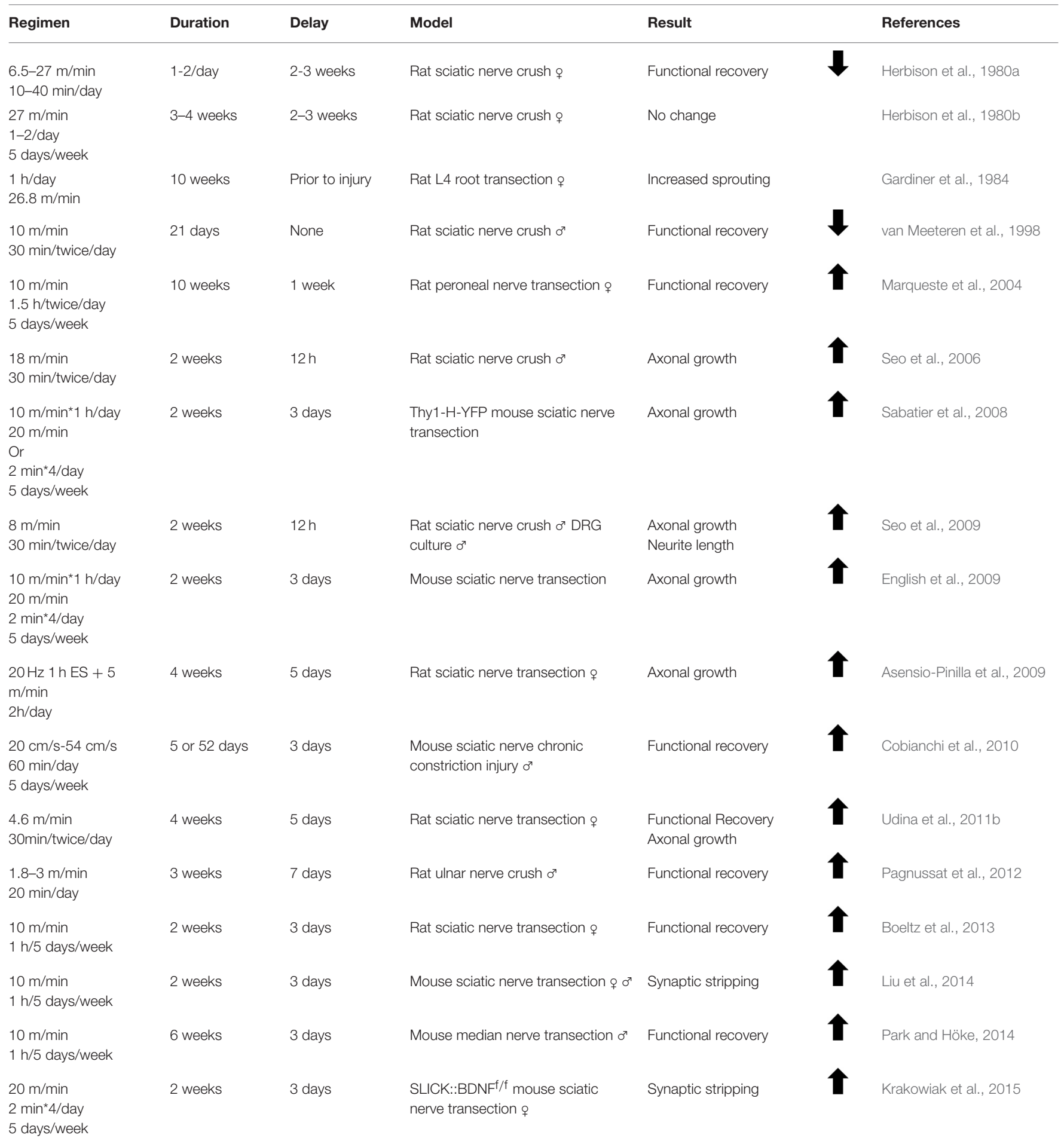

Regimen is the speed of running and for how long each day. Duration is how many days $T \pi$ was performed. Delay refers to how long after injury before exercise was performed. Model specifies what type of injury and in what animal. Sex of animals is specified by o or or. If this is not listed, it was not specified. Result specifies what outcome measure was analyzed. Denotes improvement in outcome measured, 1 denotes worse outcome. No arrow denotes no effect.

onset of pathway preference for regenerating axons (Gordon, 2015). ES, however, dramatically increases NGF secretion from Schwann cells for 3 days following stimulation (Koppes et al.,
2014), possibly providing an earlier signal to regenerating sensory axons as to which pathways to take, and thus improving pathway targeting. 
TABLE 3 | Effect of swimming exercise on peripheral nerve regeneration.

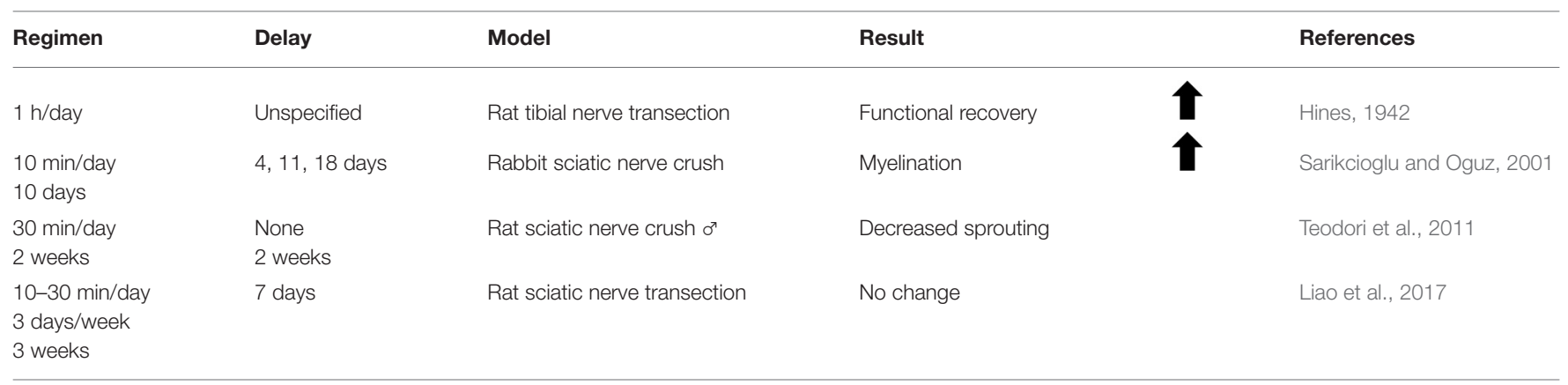

Regimen specifies how long swimming exercise lasted each day and how many days swimming was performed. Delay refers to how long after injury before exercise was performed.

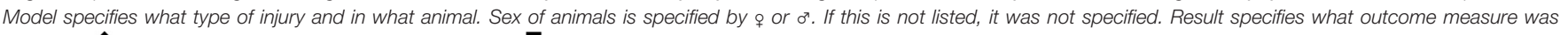
analyzed.

\section{Exercise Treatment}

For years, the evidence for exercise enhancing regeneration was not as clear as the evidence for ES. Many different types of exercise with varying intensities applied at different times prior to or after injury have resulted in conflicting results. It was hypothesized that increased neuronal activity through exercise would enhance regeneration as early as 1979, but early studies utilizing treadmill training, voluntary wheel running, and swimming found unfavorable results (Hoffer et al., 1979; Herbison et al., 1980a; Gardiner et al., 1984; Badke et al., 1989; van Meeteren et al., 1998; Tam et al., 2001). These experiments largely focused on the effect of exercise on muscle fiber alterations and muscle function, and did not probe the effect of exercise on axon regeneration.

The change in emphasis from the effect of exercise on denervated muscle to the effect of exercise on injured spinal motoneurons and DRG neurons encouraged scientists to continue researching exercise, despite previous underwhelming results. In 2008, English and colleagues tested the efficacy of interval training (short high-speed sprints followed by periods of rest) in enhancing regeneration as a model that resembles how mice voluntarily run (De Bono et al., 2006; Sabatier et al., 2008). They found the surprising result that this regimen was effective only in female mice, and in fact the more commonly used training regimen of slow continuous treadmill walking was effective only in males (Wood et al., 2012). This previously unknown sex difference could have affected outcomes in numerous exercise experiments. For example, Seo et al. treated intact male rats with either high or low intensity treadmill training before culturing their DRGs and found only low intensity treadmill training increased neurite outgrowth (Seo et al., 2009). Their treadmill training regimen was very similar to the one used by Wood et al. that proved effective only in male mice, and the results of this experiment could have been different had females been included. Many of the prior experiments mentioned used animals of only one sex, and this could explain some of the variability in the effects of exercise (Tables 2-4).

There are a few advantages to exercise over ES. For example, while ES may increase misdirection of motoneurons reaching target muscles, treadmill training enhances motoneuron regeneration without decreasing topographic specificity (English et al., 2009). The mechanism of ES is to accelerate crossing the site of injury by regenerative sprouts; exercise does the same but also sustains pro-growth signaling throughout the process of regeneration (Gordon and English, 2016). There is also evidence that the enhancing effects of 2 weeks of exercise are more robust than that of a single bout of ES (Sabatier et al., 2008; Wood et al., 2012; Gordon and English, 2016). In 2009; Asensio-Pinilla et al. combined treadmill training with a single bout of ES given at the time of injury, and found greater enhancement of muscle reinnervation in the initial phase of recovery compared to either treatment alone (Asensio-Pinilla et al., 2009). Thus, after inauspicious beginnings, exercise has shown great promise as a treatment in the field of peripheral nerve regeneration.

\section{Optogenetic Stimulation}

The advent of optogenetics enabled cell-specific neuronal activation with the use of the light-sensitive cation channel, Channelrhodopsin (ChR2) (Krook-Magnuson et al., 2014). Whereas ES stimulates all cells within the nerve (including Schwann cells and various immune cells) and exercise likely affects cells throughout the entire body, specific neuronal activation can be achieved using optogenetics by expressing ChR2 only in neurons. Park et al. were the first to demonstrate the efficacy of light stimulation in enhancing regeneration by replicating the common ES protocol using light stimulation of $20 \mathrm{~Hz}$ for $1 \mathrm{~h}$ on explanted neonatal DRGs (Park et al., 2015). Although they tested a number of different stimulation regimens, the $1 \mathrm{~h}$ of $20 \mathrm{~Hz}$ stimulation provided the largest effect on neurite outgrowth. Ward et al. recapitulated this in vivo, finding that $1 \mathrm{~h}$ of $20 \mathrm{~Hz}$ light stimulation of light-sensitive neurons enhanced axon regeneration only in the light-sensitive cells (Ward et al., 2016, 2018).

\section{MECHANISMS}

\section{Neurotrophins}

Activity-dependent treatments require neuronal neurotrophin production. ES increases neurotrophin expression in Schwann cells, DRG neurons, and motoneurons (Al Majed et al., 2000a; English et al., 2007; Wan et al., 2010; Koppes et al., 2014). 
TABLE 4 | Effect of other exercise paradigms on peripheral nerve regeneration.

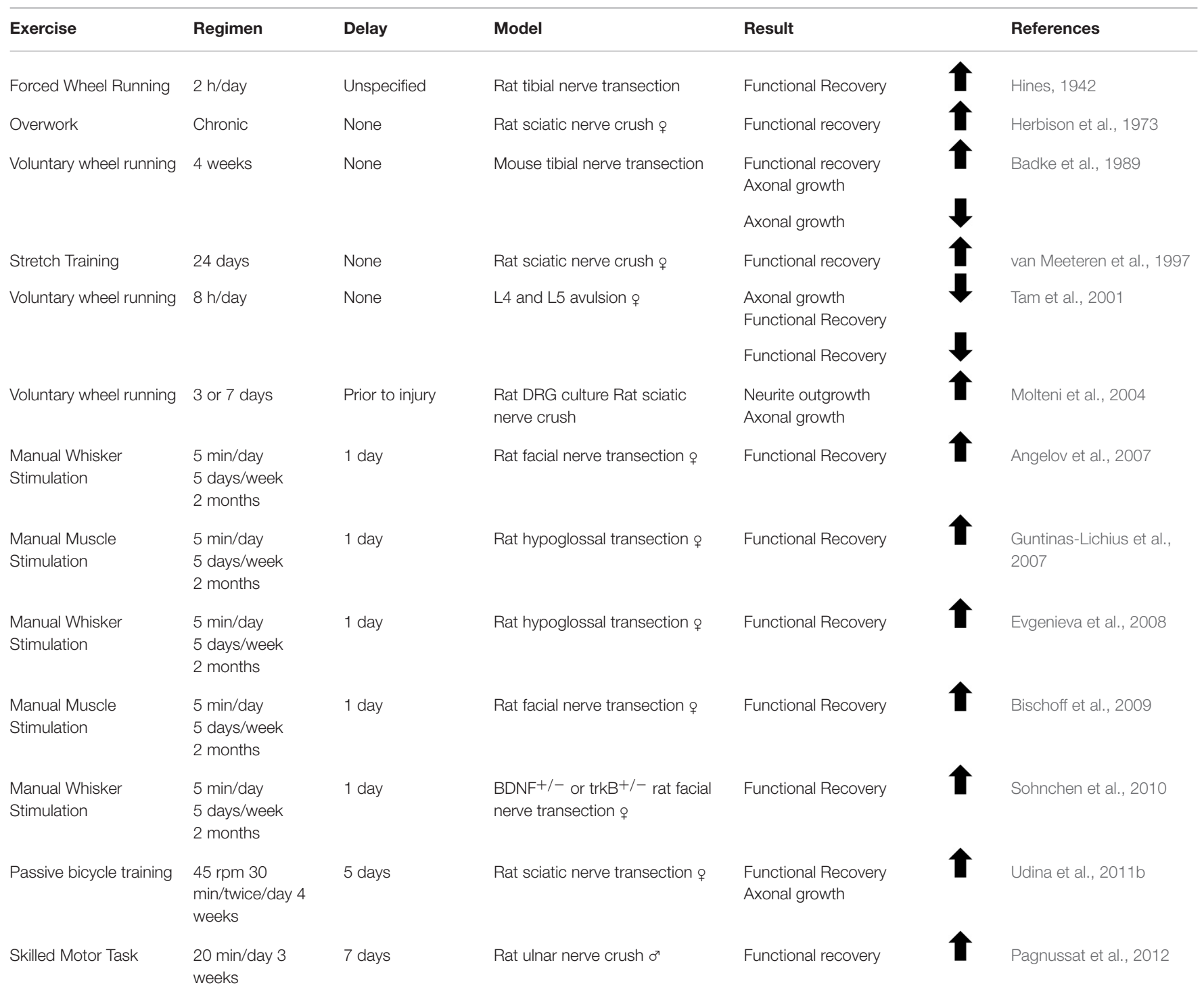

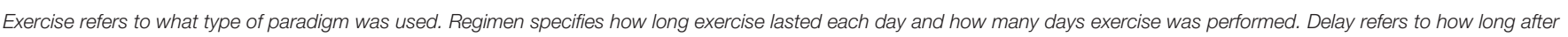

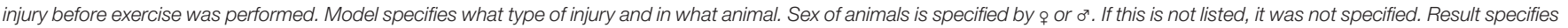
what outcome measure was analyzed.

Denotes improvement in outcome measured,

denotes worse outcome. No arrow denotes no effect.

Electrically stimulating Schwann cells increases their secretion of NGF specifically, and not BDNF (Koppes et al., 2014). While Schwann cell NGF is sufficient to promote axon growth, the study of axon regeneration through nerve grafts made acellular by repeated freezing and thawing has demonstrated that stimulation of Schwann cells (and other cell types) is not required for the efficacy of ES to enhance axon regeneration (English et al., 2007; Koppes et al., 2014). Moreover, the use of optogenetics to stimulate neurons selectively has shown that specific neuronal activation is sufficient to enhance regeneration (Ward et al., 2016). ES is also effective in promoting regeneration in nerves that have been repaired months after injury, when Schwann cells have stopped secreting neurotrophins and have started to die off (Sulaiman and Gordon, 2000; Hoke et al., 2006; Brushart et al., 2013; Huang et al., 2013; Elzinga et al., 2015). Thus, while activity-dependent treatments may increase Schwann cell neurotrophin secretion, this is not required for their enhancing effects.

Unlike non-neuronal cells, neuronal neurotrophin secretion is required for the efficacy of activity-dependent treatments. Genetically deleting NT4/5 or BDNF from Schwann cells does not alter the efficacy of ES or treadmill training in enhancing axon growth, but deleting these neurotrophins from neurons abolishes the effectiveness of these activity-dependent treatments (English et al., 2007; Wilhelm et al., 2012). Both exercise and ES have been shown to increase neuronal BDNF and its receptor, 
TABLE 5 | Effect of optogenetic stimulation on peripheral nerve regeneration.

\begin{tabular}{|c|c|c|c|c|}
\hline Regimen & Mouse & Model & Result & References \\
\hline $\begin{array}{l}1 \mathrm{~h} \\
20 \mathrm{~Hz} \\
5 \mathrm{~ms} \text { pulse }\end{array}$ & Thy 1 ChR2 & Neonate DRG explant & Neurite outgrowth & Park et al., 2015 \\
\hline $\begin{array}{l}1 \mathrm{~h} \\
20 \mathrm{~Hz} \\
1 \mathrm{~ms} \text { pulse }\end{array}$ & Thy 1 ChR2 & Sciatic nerve transection & Axonal outgrowth & Ward et al., 2016 \\
\hline $\begin{array}{l}1-2 \mathrm{~h} \\
10-20 \mathrm{~Hz}(72 \mathrm{k} \\
\text { pulse total) } \\
1 \mathrm{~ms} \text { pulse }\end{array}$ & $\begin{array}{l}\text { Avil-Cre::ChR2-YFPf/f } \\
\text { Chat-ChR2-YFP }\end{array}$ & Sciatic nerve transection & Axonal outgrowth & Ward et al., 2018 \\
\hline
\end{tabular}

trkB (Al Majed et al., 2000a; Gomez-Pinilla et al., 2002; English et al., 2007; Park and Höke, 2014; Park et al., 2015). Through coculturing light-sensitive DRG explants with wild type DRGs, Park et al. demonstrated that the BDNF secreted in response to light stimulation was sufficient to increase neurite outgrowth not only from cells in a light-sensitive (ChR2-expressing) DRG, but also in neighboring ganglia derived from wild type mice. Protein analysis of the media revealed increased BDNF and NGF secretion in response to optical stimulation from the light-sensitive DRGs only (Park et al., 2015).

There is a dose-dependence in activity-dependent treatments for enhancing nerve regeneration. Whereas $1 \mathrm{~h}$ of $20 \mathrm{~Hz}$ stimulation has been shown to enhance DRG regeneration after injury, an increase to just $3 \mathrm{~h}$ of ES decreased sensory neuron regeneration, and was associated with a downregulation in expression of the regeneration associated gene, GAP-43 (Geremia et al., 2007). In vitro, neurites from DRG explants containing ChR2 had higher rates of growth with stimulation paradigms resulting in $72 \mathrm{k}$ pulses of light $(1 \mathrm{~h} 20 \mathrm{~Hz}, 2 \mathrm{~h}$ $10 \mathrm{~Hz}, 4 \mathrm{~h} 5 \mathrm{~Hz}$ ) than stimulation paradigms that resulted in a higher number of pulses $(20 \mathrm{~Hz}$ for $1-3$ days $)$ or much lower number of pulses $(20 \mathrm{~Hz}$ for $15 \mathrm{~min}$ ) (Park et al., 2015). Three days of continuous depolarization through ES or high concentrations of $\mathrm{KCl}$ results in complete failure of dissociated DRG neurons to grow neurites in culture (Enes et al., 2010). For motoneurons, high intensity exercise or repeated bouts of ES result in decreased sprouting and fewer synaptic contacts at neuromuscular junctions (Tam et al., 2001). Application of $1 \mathrm{~h}$ of $20 \mathrm{~Hz}$ ES every third day for 2 weeks after sciatic nerve transection and repair did not enhance the regeneration of motor axons in mice (Park et al., under review). Interestingly, exogenous application of BDNF resulted in a dosedependent enhancement of axon regeneration as well (Boyd and Gordon, 2002). Low to modest doses produced enhanced axon regeneration, but higher doses inhibited regeneration. Treatments with high doses of BDNF caused $\mathrm{p} 75^{\mathrm{NTR}}$ activation, which prevented DRG neurite outgrowth (Boyd and Gordon, 2002).

\section{Neuronal Activity}

The success of activity-dependent treatments in promoting axon regeneration requires activation of the injured neurons. Treating the neurons proximal to the stimulation site with tetrodotoxin (TTX) to block their ability to conduct antidromic action potentials abolishes the effect of ES, despite the continued orthodromic firing of distal axons and muscle fibers (Al Majed et al., 2000b). Similarly, inhibition of motoneuron activity during treadmill training, using bioluminescent optogenetics (BL-OG), abolishes the enhancing effect of exercise on motoneuron regeneration (Jaiswal et al., 2017). Whether the increased activation needed to promote axon regeneration requires action potential generation is not entirely clear. Enhancement of regeneration of axons of many more motoneurons than are likely to be brought into full activity is found after treatments with exercise at a slow treadmill speed (Gordon and English, 2016). Simply increasing the excitability of injured neurons using chemogenetics could be sufficient to enhance regeneration (Jaiswal et al., 2018).

Although Park et al. found that BDNF secretion from neighbors can stimulate regeneration in neurons that were not activated in vitro, optogenetic stimulation in vivo of only motoneuron axons did not enhance DRG axon regeneration, nor vice versa (Ward et al., 2018). When BDNF is knocked out in only a subset of neurons, those specific neurons do not benefit from exercise treatment (Wilhelm et al., 2012). Thus, it appears neuronal BDNF is acting as an autocrine signal facilitating enhanced regeneration (English et al., 2014; Gordon, 2016).

\section{Androgens}

The sex difference found in response to different exercise regimens led to the hypothesis that androgen receptor signaling was involved in activity-dependent treatments. The effect of androgens in enhancing peripheral nerve regeneration had already been thoroughly explored several years prior (Fargo et al., 2009). All motoneurons contain androgen receptors, though testosterone is not required for spontaneous regenerationtreating animals of both sexes with the androgen receptor 
blocker flutamide does not inhibit regeneration, nor does castration of males (Freeman et al., 1995; Thompson et al., 2013). Application of exogenous androgens in males and females, however, enhances axon regeneration in both cranial and spinal nerve injuries (Kujawa et al., 1989, 1991; Jones, 1993; Freeman et al., 1995; Tanzer and Jones, 1997; Brown et al., 1999). This effect is androgen receptor-dependent, and blocking the androgen receptor with flutamide prevents testosterone-induced enhanced regeneration (Kujawa et al., 1995). In females, treating mice with anastrazole, an aromatase inhibitor which blocks the conversion of testosterone into estradiol, also dramatically enhanced axon regeneration, without increasing serum androgen levels (Thompson et al., 2013).

The sex difference in response to exercise regimens was evidence that androgen receptor signaling and activitydependent treatments were linked. Slow, continuous treadmill training resulted in an increase in serum testosterone levels in males, though no similar increase was found for females with interval training (Wood et al., 2012). Castrating males prior to treadmill training abolishes its enhancing effect, which cannot be rescued with interval training (Wood et al., 2012). Treating both sexes with flutamide before appropriate exercise regimens abolishes the effectiveness of this treatment in enhancing peripheral nerve regeneration (Thompson et al., 2013). Testosterone is also necessary for the beneficial effects of ES-castrated rats treated with ES have poorer regeneration compared to littermates who are treated with exogenous testosterone (Hetzler et al., 2008; Sharma et al., 2009). As with exercise, flutamide blocks the enhancing effects of ES in both males and females (Thompson et al., 2013). Conversely, combined exogenous androgen treatment with ES enhances facial nerve regeneration in gonadally intact rats (Sharma et al., 2010b).

Androgens regulate $\mathrm{BDNF}$ and its receptor, $\operatorname{trkB}$, in motoneurons (Osborne et al., 2007; Ottem et al., 2010; Sharma et al., 2010a; Verhovshek et al., 2010). Exercise elicits an upregulation of testosterone that is sustained and could result in an increased duration of BDNF and trkB expression (Thompson et al., 2013; English et al., 2014). ES elicits an early increase in BDNF expression, whereas exogenous androgen application results in a later and longer-duration increase in expression. Combining the two treatments results in an additive upregulation of BDNF and could explain the improved recovery over either treatment alone (Sharma et al., 2010a).

\section{SYNAPTIC REARRANGEMENTS}

After peripheral nerve injury both excitatory and inhibitory synaptic inputs onto injured motoneurons are withdrawn (Blinzinger and Kreutzberg, 1968; Brannstrom and Kellerth, 1998; Linda et al., 2000; Oliveira et al., 2004). If motor axons regenerate and reinnervate muscle targets, many of these inputs are restored but, for those expressing the vesicular glutamate transporter 1 (VGLUT1) and arising from muscle spindles, a gradual withdrawal of their central axonal processes from the ventral horn follows, resulting in a permanent loss of these synaptic inputs (Alvarez et al., 2011; Rotterman et al., 2014). In animals treated with exercise during the first few days following sciatic nerve transection and repair, the extent of synaptic contacts between these important sources of proprioceptive feedback and motoneurons is not reduced (English et al., 2011; Liu et al., 2014; Krakowiak et al., 2015). This robust connectivity by VGLUT1+ inputs is retained at least 12 weeks later. No similar effect is found if the onset of the exercise treatment is delayed (Brandt et al., 2015). Application of $1 \mathrm{~h}$ of $20 \mathrm{~Hz}$ ES had no effect on synaptic coverage after nerve injury, but repeated applications every third day for 2 weeks resulted in an effect similar to that observed using exercise (Park et al., under review). It is not clear whether this effect of these activity-dependent therapies is the prevention of the original synaptic withdrawal, a stimulation of new synapse formation to replace the withdrawn inputs, or some combination of both. More studies are needed.

It is clear that BDNF plays a role in maintaining and preserving synaptic inputs on motoneurons. Without exercise, axotomized motoneurons lose approximately $35 \%$ of their overall synaptic coverage (Krakowiak et al., 2015). This effect is BDNFdependent-knocking out BDNF in a subset of motoneurons reduces synaptic coverage in those specific cells in intact animals, and this synapse loss cannot be rescued with exercise (Krakowiak et al., 2015). Wild-type motoneurons within an animal maintain their synaptic contacts after nerve injury with exercise, but those in which BDNF has been knocked out do not (Krakowiak et al., 2015).

\section{BDNF VAL66MET POLYMORPHISM}

Given the relationship between activity-dependent treatments and BDNF, any genetic mutations altering BDNF signaling among the human population could affect the success of these treatments. Such a mutation exists-a common single nucleotide polymorphism in the BDNF gene. The G to A mutation at site 196 results in a Valine to Methionine substitution in the 66th codon (Figure 1). This polymorphism was first described by Egan et al. in 2003 and was quickly identified as incredibly common-the met allele of the BDNF gene is present in $25 \%$ of the American population and up to $50 \%$ of East Asian populations (Egan et al., 2003; Shimizu et al., 2004). Carrying the met allele was originally described as a risk factor for schizophrenia (Egan et al., 2003). It has since been linked to numerous other disorders and diseases, including Alzheimer's disease, obsessive compulsive disorder, anorexia nervosa, and bipolar disorder (Neves-Pereira et al., 2002; Sklar et al., 2002; Egan et al., 2003; Hall et al., 2003; Ribases et al., 2003; Notaras et al., 2015). Physiologically, Met-carriers have been found to have decreased hippocampal volume, and cells transfected with the Met allele have altered activity-dependent secretion of BDNF (Egan et al., 2003).

Testing for deficient activity-dependent secretion of BDNF in humans can be tricky. Generally, BDNF secretion is measured through serum as an indirect measure of neuronal BDNF, and exercise is a reliable method to increase serum BDNF levels (Berchtold et al., 2005; Elfving et al., 2010; Klein et al., 2011; Szuhany et al., 2015). Although one study has found that healthy 
adult Met-carriers did have increased serum BDNF after exercise (Helm et al., 2017), others have found serum levels of BDNF did not increase after high intensity exercise in elderly (Nascimento et al., 2015), spinal cord injured (Leech and Hornby, 2017), or healthy Met-carriers (Lemos et al., 2015). In mice expressing the met allele, exercise results in deficient mRNA production as well as decreased protein expression of BDNF (Ieraci et al., 2016). These deficiencies in exercise-induced BDNF secretion mirror the findings in cultured neurons expressing the Met allele, and the use of cells transfected with the met allele in vitro as well as the development of a transgenic mouse have allowed researchers to elucidate the mechanism behind this deficient secretion (Egan et al., 2003; Chen et al., 2004, 2006).

The valine to methionine substitution in this SNP occurs in the prodomain of the BDNF protein (Egan et al., 2003). Although it does not affect the ability of mBDNF to bind its receptor, this substitution results in disorganized folding of the prodomain, resulting in abnormal interactions with sortilin (see

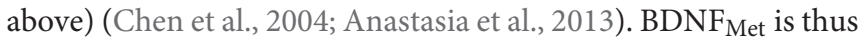
packaged inefficiently into calcium-sensitive secretory vesicles, accounting for the deficient activity-dependent secretion that has been reported (Chen et al., 2004). Being heterozygous for the met allele does not protect from this deficient BDNF secretion$\mathrm{BDNF}$ forms homodimers, and in cells heterozygous for the met allele, $\mathrm{BDNF}_{\mathrm{Met}}$ dimerizes with $\mathrm{BDNF}_{\mathrm{Val}}$ and prevents its packaging into $\mathrm{Ca}^{2+}$-regulated secretory vesicles (Kolbeck et al., 1994; Chen et al., 2004). Analysis of activity-induced BDNF secretion from cultured hippocampal cells bears this out-those cells heterozygous for the Met allele have deficient activitydependent secretion despite the presence of one copy of the $\mathrm{BDNF}_{\text {Val }}$ allele (Chen et al., 2006). Furthermore, once secreted, BDNF availability may be affected by binding with the cleaved prodomain. The prodomain binds BDNF with high affinity, and the met allele results in enhanced BDNF binding and slower dissociation once bound (Uegaki et al., 2017). This could limit the availability of BDNF to bind its receptors.

Activity-dependent secretion of BDNF relies not only on packaging into calcium-sensitive vesicles, but also on the spatial targeting of mRNA into distal processes where BDNF can be locally translated (Chiaruttini et al., 2008). This targeting is achieved through binding of BDNF mRNA with translin, a DNA/RNA binding protein involved in dendritic trafficking of mRNAs (Li et al., 2008). The G to A mutation at site 196 disrupts translin binding of BDNF mRNA, and thus Metcarriers have deficient trafficking of BDNF mRNA to distal processes (Chiaruttini et al., 2009). Moreover, the transcripts containing exon VI, which is upregulated by exercise, and exon IV, which is calcium-sensitive, are found in reduced levels in the hippocampus of mice homozygous for the met allele (Tao et al., 1998; Baj et al., 2012; Mallei et al., 2015). These transcripts, along with those containing exon II, are generally trafficked to distal processes (Baj et al., 2011).

In addition to deficient activity-dependent BDNF secretion, the met allele may result in increased $\mathrm{p} 75^{\mathrm{NTR}}$ activation. Unlike $\mathrm{BDNF}_{\mathrm{Val}}$, when the prodomain is cleaved from $\mathrm{BDNF}_{\text {Met }}$, it is bioactive and able to activate $\mathrm{p} 75^{\mathrm{NTR}}$ with the help of SorCS2, a member of the sortilin family of receptors (Deinhardt et al.,
2011; Anastasia et al., 2013). In vitro, application of exogenous prodomain protein results in growth cone collapse and dendritic spine disassembly (Anastasia et al., 2013; Giza et al., 2018). Stimulating cells with high $\mathrm{KCl}$ concentration results in activitydependent secretion of both Val and Met prodomains, though secretion is deficient in Met-carriers (Anastasia et al., 2013). Although endogenous secretion of the Met prodomain has yet to be linked to alterations in dendrites, decreased arborization has been found in hippocampal and cortical neurons (Chen et al., 2006; Liu et al., 2012).

The deficit in activity-dependent release of BDNF led to the hypothesis that activity-dependent treatments to enhance axon regeneration after peripheral nerve injury would be ineffective in this population. Using a mouse model of this polymorphism which recapitulates certain phenotypic aspects of the human population such as decreased hippocampal volume and increased anxiety-like behavior (Chen et al., 2006), we tested the efficacy of treadmill training on motor axon regeneration 4 weeks after complete sciatic nerve transection and repair in mice both heterozygous and homozygous for the met allele of the Bdnf gene (McGregor et al., under review). Exercise was completely ineffective in enhancing axon regeneration in the Met-carriers. However, peripheral axon regeneration in Met-carriers was surprisingly enhanced without any treatment (McGregor et al., under review). One possibility for the failure of exercise to enhance regeneration in Met-carriers is a ceiling effectexercise was not able to further enhance an already accelerated regeneration. The question of why regeneration is accelerated remains to be explored. The enhanced regeneration was found both in vivo and in cultured DRG neurons, indicating that enhanced axon outgrowth is a neuronal trait in Met-carriers. This unanticipated result is some of the first good news regarding what is a maligned SNP, although others have reported the met allele may also be protective in stroke and traumatic brain injury (Krueger et al., 2011; Rostami et al., 2011; Qin et al., 2014; Failla et al., 2015). Thus, in human populations there may be striking differences in response to peripheral nerve injury dependent on individual gene expression. Enhanced regeneration associated with the Val66Met polymorphism may explain the persistence of the mutation within the human population.

\section{CONCLUSION}

The suboptimal regeneration of peripheral nerves presents a challenge in medical care. Neurotrophins, particularly BDNF, have been studied for their pro-growth properties, and treatments that stimulate endogenous release of neurotrophins have been successful in enhancing regeneration in animal models. These treatments are currently being tested to enhance peripheral nerve regeneration in patients with some success (Gordon et al., 2010; Wong et al., 2015). The existence of genetic polymorphisms in the $b d n f$ gene, however, will affect the outcome of these experiments, and preliminary investigations as to the efficacy of activity-dependent treatments in individuals with the met allele will hopefully spur the field toward personalized medicine. Activity-dependent treatments can be a 
powerful tool for those responsive to them, and for the rest, new therapies that do not rely on endogenous BDNF-signaling must be developed.

\section{AUTHOR CONTRIBUTIONS}

All authors listed have made a substantial, direct and intellectual contribution to the work, and approved it for publication.

\section{REFERENCES}

Abe, N., Borson, S. H., Gambello, M. J., Wang, F., and Cavalli, V. (2010). Mammalian target of rapamycin (mTOR) activation increases axonal growth capacity of injured peripheral nerves. J. Biol. Chem. 285, 28034-28043. doi: 10.1074/jbc.M110.125336

Acheson, A., Conover, J. C., Fandl, J. P., Dechiara, T. M., Russell, M., Thadani, A., et al. (1995). A BDNF autocrine loop in adult sensory neurons prevents cell death. Nature 374, 450-453. doi: 10.1038/374450a0

Ahlborn, P., Schachner, M., and Irintchev, A. (2007). One hour electrical stimulation accelerates functional recovery after femoral nerve repair. Exp. Neurol. 208, 137-144. doi: 10.1016/j.expneurol.2007.08.005

Aid, T., Kazantseva, A., Piirsoo, M., Palm, K., and Timmusk, T. (2007). Mouse and rat BDNF gene structure and expression revisited. J. Neurosci. Res. 85, 525-535. doi: 10.1002/jnr.21139

Al Majed, A., Brushart, T., and Gordon, T. (2000a). Electrical stimulation accelerates and increases expression of BDNF and trkB mRNA in regenerating rat femoral motoneurons. Eur. J. Neurosci. 12, 4381-4390. doi: $10.1046 /$ j.1460-9568.2000.01341.x

Al Majed, A., Neumann, C., Brushart, T., and Gordon, T. (2000b). Brief electrical stimulation promotes the speed and accuracy of motor axonal regeneration. J. Neurosci. 20, 2602-2608. doi: 10.1523/JNEUROSCI.20-07-02602.2000

Alderson, R. F., Curtis, R., Alterman, A. L., Lindsay, R. M., and Distefano, P. S. (2000). Truncated TrkB mediates the endocytosis and release of BDNF and neurotrophin- $4 / 5$ by rat astrocytes and Schwann cells in vitro. Brain Res. 871, 210-222. doi: 10.1016/S0006-8993(00)02428-8

Allen, M., Bird, C., Feng, W., Liu, G., Li, W., Perrone-Bizzozero, N. I., et al. (2013). HuD promotes BDNF expression in brain neurons via selective stabilization of the BDNF long 3'UTR mRNA. PLoS ONE 8:e55718. doi: 10.1371/journal.pone.0055718

Alvarez, F. J., Titus-Mitchell, H. E., Bullinger, K. L., Kraszpulski, M., Nardelli, P., and Cope, T. C. (2011). Permanent central synaptic disconnection of proprioceptors after nerve injury and regeneration. I. Loss of VGLUT1/IA synapses on motoneurons. J. Neurophysiol. 106, 2450-2470. doi: $10.1152 /$ jn. 01095.2010

An, J. J., Gharami, K., Liao, G. Y., Woo, N. H., Lau, A. G., Vanevski, F., et al. (2008). Distinct role of long $3^{\prime}$ Utr Bdnf Mrna in spine morphology and synaptic plasticity in hippocampal neurons. Cell 134, 175-187. doi: 10.1016/j.cell.2008.05.045

Anastasia, A., Deinhardt, K., Chao, M., Will, N., Irmady, K., Lee, F., et al. (2013). Val66Met polymorphism of BDNF alters prodomain structure to induce neuronal growth cone retraction. Nat. Commun. 4:2490. doi: $10.1038 /$ ncomms 3490

Angelov, D. N., Ceynowa, M., Guntinas-Lichius, O., Streppel, M., Grosheva, M., Kiryakova, S. I., et al. (2007). Mechanical stimulation of paralyzed vibrissal muscles following facial nerve injury in adult rat promotes full recovery of whisking. Neurobiol. Dis. 26, 229-242. doi: 10.1016/j.nbd.2006. 12.016

Apfel, S. C., Wright, D. E., Wiideman, A. M., Dormia, C., Snider, W. D., and Kessler, J. A. (1996). Nerve growth factor regulates the expression of brainderived neurotrophic factor mRNA in the peripheral nervous system. Mol. Cell. Neurosci. 7, 134-142. doi: 10.1006/mcne.1996.0010

Asano, Y., Nagasaki, A., and Uyeda, T. Q. (2008). Correlated waves of actin filaments and PIP3 in Dictyostelium cells. Cell Motil. Cytoskeleton 65, 923-934. doi: $10.1002 / \mathrm{cm} .20314$

\section{ACKNOWLEDGMENTS}

Support provided by grant NS057190 to AE from the USPHS. Many thanks to Dr. Francis Lee for the gift of the Val66Met mouse. The manuscript is based in part on a thesis for the Ph.D. degree in Neuroscience from The Laney Graduate School of Emory University (McGregor, 2018).

Asensio-Pinilla, E., Udina, E., Jaramillo, J., and Navarro, X. (2009). Electrical stimulation combined with exercise increase axonal regeneration after peripheral nerve injury. Exp. Neurol. 219, 258-265. doi: 10.1016/j.expneurol.2009.05.034

Badke, A., Irintchev, A. P., and Wernig, A. (1989). Maturation of transmission in reinnervated mouse soleus muscle. Muscle Nerve 12, 580-586. doi: $10.1002 /$ mus. 880120709

Baj, G., D’alessandro, V., Musazzi, L., Mallei, A., Sartori, C. R., Sciancalepore, M., et al. (2012). Physical exercise and antidepressants enhance BDNF targeting in hippocampal CA3 dendrites: further evidence of a spatial code for BDNF splice variants. Neuropsychopharmacology 37, 1600-1611. doi: 10.1038/npp.2012.5

Baj, G., Leone, E., Chao, M. V., and Tongiorgi, E. (2011). Spatial segregation of BDNF transcripts enables BDNF to differentially shape distinct dendritic compartments. Proc. Natl. Acad. Sci. U.S.A. 108, 16813-16818. doi: 10.1073/pnas.1014168108

Bartel, D. P. (2004). MicroRNAs: genomics, biogenesis, mechanism, and function. Cell 116, 281-297. doi: 10.1016/S0092-8674(04)00045-5

Batty, N. J., Fenrich, K. K., and Fouad, K. (2017). The role of cAMP and its downstream targets in neurite growth in the adult nervous system. Neurosci. Lett. 652, 56-63. doi: 10.1016/j.neulet.2016.12.033

Berchtold, N. C., Chinn, G., Chou, M., Kesslak, J. P., and Cotman, C. W. (2005). Exercise primes a molecular memory for brain-derived neurotrophic factor protein induction in the rat hippocampus. Neuroscience 133, 853-861. doi: $10.1016 /$ j.neuroscience.2005.03.026

Bibel, M., Hoppe, E., and Barde, Y. A. (1999). Biochemical and functional interactions between the neurotrophin receptors trk and p75NTR. EMBO J. 18, 616-622. doi: 10.1093/emboj/18.3.616

Bischoff, A., Grosheva, M., Irintchev, A., Skouras, E., Kaidoglou, K., Michael, J., et al. (2009). Manual stimulation of the orbicularis oculi muscle improves eyelid closure after facial nerve injury in adult rats. Muscle Nerve 39, 197-205. doi: 10.1002/mus.21126

Blinzinger, K., and Kreutzberg, G. (1968). Displacement of synaptic terminals from regenerating motoneurons by microglial cells. Z. Zellforsch. Mikrosk. Anat. 85, 145-157. doi: 10.1007/BF00325030

Boeltz, T., Ireland, M., Mathis, K., Nicolini, J., Poplavski, K., Rose, S., et al. (2013). Effects of treadmill training on functional recovery following peripheral nerve injury in rats. J. Neurophysiol. 109, 2645-2657. doi: 10.1152/jn.00946.2012

Boyd, J. G., and Gordon, T. (2001). The neurotrophin receptors, trkB and p75, differentially regulate motor axonal regeneration. J. Neurobiol. 49, 314-325. doi: $10.1002 /$ neu. 10013

Boyd, J. G., and Gordon, T. (2002). A dose-dependent facilitation and inhibition of peripheral nerve regeneration by brain-derived neurotrophic factor. Eur. J. Neurosci. 15, 613-626. doi: 10.1046/j.1460-9568.2002.01891.x

Boyd, J. G., and Gordon, T. (2003). Neurotrophic factors and their receptors in axonal regeneration and functional recovery after peripheral nerve injury. Mol. Neurobiol. 27, 277-324. doi: 10.1385/MN:27:3:277

Brandt, J., Evans, J. T., Mildenhall, T., Mulligan, A., Konieczny, A., Rose, S. J., et al. (2015). Delaying the onset of treadmill exercise following peripheral nerve injury has different effects on axon regeneration and motoneuron synaptic plasticity. J. Neurophysiol. 113, 2390-2399. doi: 10.1152/jn.00892.2014

Brannstrom, T., and Kellerth, J. O. (1998). Changes in synaptology of adult cat spinal alpha-motoneurons after axotomy. Exp. Brain Res. 118, 1-13. doi: $10.1007 / \mathrm{s} 002210050249$

Brigadski, T., Hartmann, M., and Lessmann, V. (2005). Differential vesicular targeting and time course of synaptic secretion of 
the mammalian neurotrophins. J. Neurosci. 25, 7601-7614. doi: 10.1523/JNEUROSCI.1776-05.2005

Brown, T. J., Khan, T., and Jones, K. J. (1999). Androgen induced acceleration of functional recovery after rat sciatic nerve injury. Restor. Neurol. Neurosci. 15, 289-295.

Brushart, T. M. (1993). Motor axons preferentially reinnervate motor pathways. J. Neurosci. 13, 2730-2738. doi: 10.1523/JNEUROSCI.13-06-02730.1993

Brushart, T. M., Aspalter, M., Griffin, J. W., Redett, R., Hameed, H., Zhou, C., et al. (2013). Schwann cell phenotype is regulated by axon modality and central-peripheral location, and persists in vitro. Exp. Neurol. 247, 272-281. doi: 10.1016/j.expneurol.2013.05.007

Brushart, T. M., Hoffman, P. N., Royall, R. M., Murinson, B. B., Witzel, C., and Gordon, T. (2002). Electrical stimulation promotes motoneuron regeneration without increasing its speed or conditioning the neuron. J. Neurosci. 22, 6631-6638. doi: 10.1523/JNEUROSCI.22-15-06631.2002

Brushart, T. M., Jari, R., Verge, V., Rohde, C., and Gordon, T. (2005). Electrical stimulation restores the specificity of sensory axon regeneration. Exp. Neurol. 194, 221-229. doi: 10.1016/j.expneurol.2005.02.007

Bueker, E. D., and Meyers, C. E. (1951). The maturity of peripheral nerves at the time of injury as a factor in nerve regeneration. Anat. Rec. 109, 723-743. doi: 10.1002/ar.1091090409

Cai, D., Shen, Y., De Bellard, M., Tang, S., and Filbin, M. T. (1999). Prior exposure to neurotrophins blocks inhibition of axonal regeneration by MAG and Myelin via a cAMP-dependent mechanism. Neuron 22, 89-101. doi: 10.1016/S0896-6273(00)80681-9

Capsoni, S., Tongiorgi, E., Cattaneo, A., and Domenici, L. (1999). Dark rearing blocks the developmental down-regulation of brain-derived neurotrophic factor messenger RNA expression in layers IV and V of the rat visual cortex. Neuroscience 88, 393-403. doi: 10.1016/S0306-4522(98)00 250-4

Carter, B. D., Kaltschmidt, C., Kaltschmidt, B., Offenhauser, N., Bohm-Matthaei, R., Baeuerle, P. A., et al. (1996). Selective activation of NF-kappa B by nerve growth factor through the neurotrophin receptor p75. Science 272, 542-545. doi: $10.1126 /$ science. 272.5261 .542

Chen, Z., Jing, D., Bath, K., Ieraci, A., Khan, T., Siao, C., et al. (2006). Genetic variant BDNF (Val66Met) polymorphism alters anxiety-related behavior. Science 314, 140-143. doi: 10.1126/science.1129663

Chen, Z., Patel, P., Sant, G., Meng, C., Teng, K., Hempstead, B., et al. (2004). Variant brain-derived neurotrophic factor (BDNF) (Met66) alters the intracellular trafficking and activity-dependent secretion of wild-type BDNF in neurosecretory cells and cortical neurons. J. Neurosci. 24, 4401-4411. doi: 10.1523/JNEUROSCI.0348-04.2004

Chen, Z. Y., Ieraci, A., Teng, H., Dall, H., Meng, C. X., Herrera, D. G., et al. (2005). Sortilin controls intracellular sorting of brain-derived neurotrophic factor to the regulated secretory pathway. J. Neurosci. 25, 6156-6166. doi: 10.1523/JNEUROSCI.1017-05.2005

Chiaruttini, C., Sonego, M., Baj, G., Simonato, M., and Tongiorgi, E. (2008). Bdnf mRNA splice variants display activity-dependent targeting to distinct hippocampal laminae. Mol. Cell. Neurosci. 37, 11-19. doi: 10.1016/j.mcn.2007.08.011

Chiaruttini, C., Vicario, A., Li, Z., Baj, G., Braiuca, P., Wu, Y., et al. (2009). Dendritic trafficking of BDNF mRNA is mediated by translin and blocked by the G196A (Val66Met) mutation. Proc. Natl. Acad. Sci. U.S.A. 106, 16481-16486. doi: 10.1073/pnas.0902833106

Cho, H. J., Kim, S. Y., Park, M. J., Kim, D. S., Kim, J. K., and Chu, M. Y. (1997). Expression of mRNA for brain-derived neurotrophic factor in the dorsal root ganglion following peripheral inflammation. Brain Res. 749, 358-362. doi: 10.1016/S0006-8993(97)00048-6

Christie, K. J., Webber, C. A., Martinez, J. A., Singh, B., and Zochodne, D. W. (2010). PTEN inhibition to facilitate intrinsic regenerative outgrowth of adult peripheral axons. J. Neurosci. 30, 9306-9315. doi: 10.1523/JNEUROSCI.6271-09.2010

Cobianchi, S., Marinelli, S., Florenzano, F., Pavone, F., and Luvisetto, S. (2010). Short- but not long-lasting treadmill running reduces allodynia and improves functional recovery after peripheral nerve injury. Neuroscience 168, 273-287. doi: 10.1016/j.neuroscience.2010.03.035

Conner, J. M., Lauterborn, J. C., Yan, Q., Gall, C. M., and Varon, S. (1997). Distribution of Brain-Derived Neurotrophic Factor (BDNF) protein and
mRNA in the normal adult rat CNS: evidence for anterograde axonal transport. J. Neurosci. 17, 2295-2313. doi: 10.1523/JNEUROSCI.17-07-02295.1997

Cosgaya, J. M., Chan, J. R., and Shooter, E. M. (2002). The neurotrophin receptor p75NTR as a positive modulator of myelination. Science 298, 1245-1248. doi: $10.1126 /$ science. 1076595

Davis-Lopez de Carrizosa, M. A., Morado-Diaz, C. J., Tena, J. J., BenitezTemino, B., Pecero, M. L., Morcuende, S. R., et al. (2009). Complementary actions of BDNF and neurotrophin-3 on the firing patterns and synaptic composition of motoneurons. J. Neurosci. 29, 575-587. doi: 10.1523/JNEUROSCI.5312-08.2009

De Bono, J. P., Adlam, D., Paterson, D. J., and Channon, K. M. (2006). Novel quantitative phenotypes of exercise training in mouse models. Am. J. Physiol. Regul. Integr. Comp. Physiol. 290, R926-R934. doi: 10.1152/ajpregu.00694.2005

Dechant, G., and Barde, Y.-A. (1997). Signalling through the neurotrophin receptor p75NTR. Curr. Opin. Neurobiol. 7, 413-418. doi: 10.1016/S0959-4388(97)80071-2

Dechant, G., and Barde, Y. A. (2002). The neurotrophin receptor p75(NTR): novel functions and implications for diseases of the nervous system. Nat. Neurosci. 5, 1131-1136. doi: 10.1038/nn1102-1131

Deinhardt, K., Kim, T., Spellman, D. S., Mains, R. E., Eipper, B. A., Neubert, T. A., et al. (2011). Neuronal growth cone retraction relies on proneurotrophin receptor signaling through Rac. Sci Signal 4:ra82. doi: $10.1126 /$ scisignal.2002060

Delcroix, J.-D., Valletta, J. S., Wu, C., Hunt, S. J., Kowal, A. S., and Mobley, W. C. (2003). NGF signaling in sensory neurons: evidence that early endosomes carry NGF retrograde signals. Neuron 39, 69-84. doi: 10.1016/S0896-6273(03)00397-0

Diamond, J., Coughlin, M., Macintyre, L., Holmes, M., and Visheau, B. (1987). Evidence that endogenous beta nerve growth factor is responsible for the collateral sprouting, but not the regeneration, of nociceptive axons in adult rats. Proc. Natl. Acad. Sci. U.S.A. 84, 6596-6600. doi: 10.1073/pnas.84.18.6596

Diamond, J., Foerster, A., Holmes, M., and Coughlin, M. (1992). Sensory nerves in adult rats regenerate and restore sensory function to the skin independently of endogenous NGF. J. Neurosci. 12, 1467-1476. doi: 10.1523/JNEUROSCI.12-04-01467.1992

Dieni, S., Matsumoto, T., Dekkers, M., Rauskolb, S., Ionescu, M. S., Deogracias, R., et al. (2012). BDNF and its pro-peptide are stored in presynaptic dense core vesicles in brain neurons. J. Cell Biol. 196, 775-788. doi: 10.1083/jcb.201201038

Difato, F., Tsushima, H., Pesce, M., Benfenati, F., Blau, A., and Chieregatti, E. (2011). The formation of actin waves during regeneration after axonal lesion is enhanced by BDNF. Sci. Rep. 1:183. doi: 10.1038/srep00183

Egan, M., Kojima, M., Callicott, J., Goldberg, T., Kolachana, B., Bertolino, A., et al. (2003). The BDNF val66met polymorphism affects activity-dependent secretion of BDNF and human memory and hippocampal function. Cell 112, 257-269. doi: 10.1016/S0092-8674(03)00035-7

Eide, F. F., Vining, E. R., Eide, B. L., Zang, K., Wang, X. Y., and Reichardt, L. F. (1996). Naturally occurring truncated trkB receptors have dominant inhibitory effects on brain-derived neurotrophic factor signaling. J. Neurosci. 16, 3123-3129. doi: 10.1523/JNEUROSCI.16-10-03123.1996

Elfving, B., Plougmann, P. H., and Wegener, G. (2010). Detection of brainderived neurotrophic factor (BDNF) in rat blood and brain preparations using ELISA: Pitfalls and solutions. J. Neurosci. Methods 187, 73-77. doi: 10.1016/j.jneumeth.2009.12.017

Elzinga, K., Tyreman, N., Ladak, A., Savaryn, B., Olson, J., and Gordon, T. (2015). Brief electrical stimulation improves nerve regeneration after delayed repair in Sprague Dawley rats. Exp. Neurol. 269, 142-153. doi: 10.1016/j.expneurol.2015.03.022

Enes, J., Langwieser, N., Ruschel, J., Carballosa-Gonzalez, M. M., Klug, A., Traut, M. H., et al. (2010). Electrical activity suppresses axon growth through Cav1.2 channels in adult primary sensory neurons. Curr. Biol. 20, 1154-1164. doi: $10.1016 /$ j.cub. 2010.05 .055

English, A. (2005). Enhancing axon regeneration in peripheral nerves also increases functionally inappropriate reinnervation of targets. J. Comp. Neurol. 490, 427-441. doi: 10.1002/cne.20678

English, A., Cucoranu, D., Mulligan, A., and Sabatier, M. (2009). Treadmill training enhances axon regeneration in injured mouse peripheral nerves without increased loss of topographic specificity. J. Comp. Neurol. 517, 245-255. doi: $10.1002 /$ cne. 22149 
English, A., Liu, K., Nicolini, J., Mulligan, A., and Ye, K. (2013). Small-molecule trkB agonists promote axon regeneration in cut peripheral nerves. Proc. Natl. Acad. Sci. U.S.A. 110, 16217-16222. doi: 10.1073/pnas.1303646110

English, A., Schartz, G., Meador, W., Sabatier, M., and Mulligan, A. (2007). Electrical stimulation promotes peripheral axon regeneration by enhanced neuronal neurotrophin signaling. Dev. Neurobiol. 67, 158-172. doi: 10.1002/dneu.20339

English, A., Wilhelm, J., and Sabatier, M. (2011). Enhancing recovery from peripheral nerve injury using treadmill training. Ann. Anat. 193, 354-361. doi: 10.1016/j.aanat.2011.02.013

English, A. W., Wilhelm, J. C., and Ward, P. J. (2014). Exercise, neurotrophins, and axon regeneration in the PNS. Physiology 29, 437-445. doi: 10.1152/physiol.00028.2014

Ernfors, P., Henschen, A., Olson, L., and Persson, H. (1989). Expression of nerve growth factor receptor mRNA is developmentally regulated and increased after axotomy in rat spinal cord motoneurons. Neuron 2, 1605-1613. doi: 10.1016/0896-6273(89)90049-4

Escandon, E., Soppet, D., Rosenthal, A., Mendoza-Ramirez, J., Szonyi, E., Burton, L., et al. (1994). Regulation of neurotrophin receptor expression during embryonic and postnatal development. J. Neurosci. 14, 2054-2068. doi: 10.1523/JNEUROSCI.14-04-02054.1994

Evgenieva, E., Schweigert, P., Guntinas-Lichius, O., Pavlov, S., Grosheva, M., Angelova, S., et al. (2008). Manual stimulation of the suprahyoid-sublingual region diminishes polynnervation of the motor endplates and improves recovery of function after hypoglossal nerve injury in rats. Neurorehabil. Neural Repair 22, 754-768. doi: 10.1177/1545968308316387

Failla, M. D., Kumar, R., Peitzman, A., Conley, Y. P., Ferrell, R. E., and Wagner, A. K. (2015). Variation in the BDNF gene interacts with age to predict mortality in a prospective, longitudinal cohort with severe TBI. Neurorehabil. Neural Repair 29, 234-246. doi: $10.1177 / 1545968314542617$

Fargo, K. N., Foecking, E. M., Jones, K. J., and Sengelaub, D. R. (2009). Neuroprotective actions of androgens on motoneurons. Front. Neuroendocrinol. 30:141. doi: 10.1016/j.yfrne.2009.04.005

Ferri, C. C., Moore, F. A., and Bisby, M. A. (1998). Effects of facial nerve injury on mouse motoneurons lacking the p75 low-affinity neurotrophin receptor. J. Neurobiol. 34, 1-9. doi: 10.1002/(SICI)1097-4695(199801)34:1<1::AID-NEU1>3.0.CO;2-C

Flynn, K. C., Pak, C. W., Shaw, A. E., Bradke, F., and Bamburg, J. R. (2009). Growth cone-like waves transport actin and promote axonogenesis and neurite branching. Dev. Neurobiol. 69, 761-779. doi: 10.1002/dneu.20734

Foecking, E. M., Fargo, K. N., Coughlin, L. M., Kim, J. T., Marzo, S. J., and Jones, K. J. (2012). Single session of brief electrical stimulation immediately following crush injury enhances functional recovery of rat facial nerve. J. Rehabil. Res. Dev. 49, 451-458. doi: 10.1682/JRRD.2011.03.0033

Freeman, L. M., Padgett, B. A., Prins, G. S., and Breedlove, S. M. (1995). Distribution of androgen receptor immunoreactivity in the spinal cord of wildtype, androgen-insensitive and gonadectomized male rats. J. Neurobiol. 27, 51-59. doi: 10.1002/neu.480270106

Frisén, J., Verge, V. M., Fried, K., Risling, M., Persson, H., Trotter, J., et al. (1993). Characterization of glial trkB receptors: differential response to injury in the central and peripheral nervous systems. Proc. Natl. Acad. Sci. U.S.A. 90, 4971-4975. doi: 10.1073/pnas.90.11.4971

Fryer, R. H., Kaplan, D. R., and Kromer, L. F. (1997). Truncated trkB receptors on nonneuronal cells inhibit BDNF-induced neurite outgrowth in vitro. Exp. Neurol. 148, 616-627. doi: 10.1006/exnr.1997.6699

$\mathrm{Fu}, \mathrm{S}$. Y., and Gordon, T. (1995a). Contributing factors to poor functional recovery after delayed nerve repair: prolonged axotomy. J. Neurosci. 15, 3876-3885. doi: 10.1523/JNEUROSCI.15-05-03876.1995

$\mathrm{Fu}$, S. Y., and Gordon, T. (1995b). Contributing factors to poor functional recovery after delayed nerve repair: prolonged denervation. J. Neurosci. 15, 3886-3895. doi: 10.1523/JNEUROSCI.15-05-03886.1995

Fukuchi, M., and Tsuda, M. (2010). Involvement of the $3^{\prime}$-untranslated region of the brain-derived neurotrophic factor gene in activitydependent mRNA stabilization. J. Neurochem. 115, 1222-1233. doi: 10.1111/j.1471-4159.2010.07016.x

Funakoshi, H., Frisen, J., Barbany, G., Timmusk, T., Zachrisson, O., Verge, V. M., et al. (1993). Differential expression of mRNAs for neurotrophins and their receptors after axotomy of the sciatic nerve. J. Cell Biol. 123, 455-465. doi: $10.1083 /$ jcb.123.2.455

Gallo, G., and Letourneau, P. C. (1998). Localized sources of neurotrophins initiate axon collateral sprouting. J. Neurosci. 18, 5403-5414. doi: 10.1523/JNEUROSCI.18-14-05403.1998

Gao, Y., Nikulina, E., Mellado, W., and Filbin, M. T. (2003). Neurotrophins elevate cAMP to reach a threshold required to overcome inhibition by MAG through extracellular signal-regulated kinase-dependent inhibition of phosphodiesterase. J. Neurosci. 23, 11770-11777. doi: 10.1523/JNEUROSCI.23-37-11770.2003

Gardiner, P. F., Michel, R., and Iadeluca, G. (1984). Previous exercise training influences functional sprouting of rat hindlimb motoneurons in response to partial denervation. Neurosci. Lett. 45, 123-127. doi: 10.1016/0304-3940(84)90086-7

Geremia, N., Gordon, T., Brushart, T., Al Majed, A., and Verge, V. (2007). Electrical stimulation promotes sensory neuron regeneration and growth-associated gene expression. Exp. Neurol. 205, 347-359. doi: 10.1016/j.expneurol.2007.01.040

Ghosh-Roy, A., Wu, Z., Goncharov, A., Jin, Y., and Chisholm, A. D. (2010). Calcium and cyclic AMP promote axonal regeneration in Caenorhabditis elegans and require DLK-1 kinase. J. Neurosci. 30, 3175-3183. doi: 10.1523/JNEUROSCI.5464-09.2010

Gibney, J., and Zheng, J. Q. (2003). Cytoskeletal dynamics underlying collateral membrane protrusions induced by neurotrophins in cultured Xenopus embryonic neurons. J. Neurobiol. 54, 393-405. doi: 10.1002/neu.10149

Giza, J. I., Kim, J., Meyer, H. C., Anastasia, A., Dincheva, I., Zheng, C. I., et al. (2018). The BDNF Val66Met prodomain disassembles dendritic spines altering fear extinction circuitry and behavior. Neuron 99, 163-178.e6. doi: 10.1016/j.neuron.2018.05.024

Goldberg, J. L., Espinosa, J. S., Xu, Y., Davidson, N., Kovacs, G. T., and Barres, B. A. (2002). Retinal ganglion cells do not extend axons by default: promotion by neurotrophic signaling and electrical activity. Neuron 33, 689-702. doi: 10.1016/S0896-6273(02)00602-5

Gomez-Pinilla, F., Ying, Z., Roy, R. R., Molteni, R., and Edgerton, V. R. (2002). Voluntary exercise induces a BDNF-mediated mechanism that promotes neuroplasticity. J. Neurophysiol. 88, 2187-2195. doi: 10.1152/jn.00152.2002

Gordon, T. (2015). "Chapter 61 - The biology, limits, and promotion of peripheral nerve regeneration in rats and humans," in Nerves and Nerve Injuries, eds R. S. Tubbs, E. Rizk, M. M. Shoja, M. Loukas, N. Barbaro, and R. J. Spinner (San Diego, CA: Academic Press), 993-1019.

Gordon, T. (2016). Electrical stimulation to enhance axon regeneration after peripheral nerve injuries in animal models and humans. Neurotherapeutics 13, 295-310. doi: 10.1007/s13311-015-0415-1

Gordon, T., Amirjani, N., Edwards, D. C., and Chan, K. M. (2010). Brief post-surgical electrical stimulation accelerates axon regeneration and muscle reinnervation without affecting the functional measures in carpal tunnel syndrome patients. Exp. Neurol. 223, 192-202. doi: 10.1016/j.expneurol.2009.09.020

Gordon, T., Chan, K. M., Sulaiman, O. A. R., Udina, E., Amirjani, N., and Brushart, T. M. (2009). Accelerating axon growth to overcome limitations in functional recovery after peripheral nerve injury Neurosurgery 65, A132-A144. doi: 10.1227/01.NEU.0000335650.09473.D3

Gordon, T., and English, A. W. (2016). Strategies to promote peripheral nerve regeneration: electrical stimulation and/or exercise. Eur. J. Neurosci. 43, 336-350. doi: 10.1111/ejn.13005

Grosheva, M., Nohroudi, K., Schwarz, A., Rink, S., Bendella, H., Sarikcioglu, L., et al. (2016). Comparison of trophic factors' expression between paralyzed and recovering muscles after facial nerve injury. A quantitative analysis in time course. Exp. Neurol. 279, 137-148. doi: 10.1016/j.expneurol.2016. 02.020

Gschwendtner, A., Liu, Z., Hucho, T., Bohatschek, M., Kalla, R., Dechant, G., et al. (2003). Regulation, cellular localization, and function of the $\mathrm{p} 75$ neurotrophin receptor (p75NTR) during the regeneration of facial motoneurons. Mol. Cell. Neurosci. 24, 307-322. doi: 10.1016/S1044-7431(03)00167-2

Gualandris, A., Jones, T. E., Strickland, S., and Tsirka, S. E. (1996). Membrane depolarization induces calcium-dependent secretion of tissue plasminogen activator. J. Neurosci. 16, 2220-2225. 
Guntinas-Lichius, O., Hundeshagen, G., Paling, T., Streppel, M., Grosheva, M., Irintchev, A., et al. (2007). Manual stimulation of facial muscles improves functional recovery after hypoglossal-facial anastomosis and interpositional nerve grafting of the facial nerve in adult rats. Neurobiol. Dis. 28, 101-112. doi: 10.1016/j.nbd.2007.07.006

Hall, D., Dhilla, A., Charalambous, A., Gogos, J. A., and Karayiorgou, M. (2003). Sequence variants of the brain-derived neurotrophic factor (BDNF) gene are strongly associated with obsessive-compulsive disorder. Am. J. Hum. Genet. 73, 370-376. doi: 10.1086/377003

Hamanoue, M., Middleton, G., Wyatt, S., Jaffray, E., Hay, R. T., and Davies, A. M. (1999). p75-mediated NF-kappaB activation enhances the survival response of developing sensory neurons to nerve growth factor. Mol. Cell. Neurosci. 14, 28-40. doi: 10.1006/mcne.1999.0770

Helm, E. E., Matt, K. S., Kirschner, K. F., Pohlig, R. T., Kohl, D., and Reisman, D. S. (2017). The influence of high intensity exercise and the Val66Met polymorphism on circulating BDNF and locomotor learning. Neurobiol. Learn. Mem. 144, 77-85. doi: 10.1016/j.nlm.2017.06.003

Herbison, G. J., Jaweed, M. M., and Ditunno, J. F. (1980a). Effect of activity and inactivity on reinnervating rat skeletal muscle contractility. Exp. Neurol. 70, 498-506. doi: 10.1016/0014-4886(80)90176-4

Herbison, G. J., Jaweed, M. M., and Ditunno, J. F. (1980b). Histochemical fiber type alterations secondary to exercise training of reinnervating adult rat muscle. Arch. Phys. Med. Rehabil. 61, 255-257.

Herbison, G. J., Jaweed, M. M., Ditunno, J. F., and Scott, C. M. (1973). Effect of overwork during reinnervation of rat muscle. Exp. Neurol. 41, 1-14. doi: 10.1016/0014-4886(73)90176-3

Hetzler, L. E. T., Sharma, N., Tanzer, L., Wurster, R. D., Leonetti, J., Marzo, S. J., et al. (2008). Accelerating functional recovery after rat facial nerve injury: effects of gonadal steroids and electrical stimulation. Otolaryngol. Head Neck Surg. 139, 62-67. doi: 10.1016/j.otohns.2008.02.006

Heuer, J. G., Fatemie-Nainie, S., Wheeler, E. F., and Bothwell, M. (1990). Structure and developmental expression of the chicken NGF receptor. Dev. Biol. 137, 287-304. doi: 10.1016/0012-1606(90)90255-H

Heumann, R., Korsching, S., Bandtlow, C., and Thoenen, H. (1987a). Changes of nerve growth factor synthesis in nonneuronal cells in response to sciatic nerve transection. J. Cell Biol. 104, 1623-1631. doi: 10.1083/jcb.104.6.1623

Heumann, R., Lindholm, D., Bandtlow, C., Meyer, M., Radeke, M. J., Misko, T. P., et al. (1987b). Differential regulation of mRNA encoding nerve growth factor and its receptor in rat sciatic nerve during development, degeneration, and regeneration: role of macrophages. Proc. Natl. Acad. Sci. U.S.A. 84, 8735-8739. doi: $10.1073 /$ pnas.84.23.8735

Hines, H. M. (1942). Effects of immobilization and activity on neuromuscular regeneration. JAMA 120, 515-517. doi: 10.1001/jama.1942.02830420023006

Hoffer, J. A., Stein, R. B., and Gordon, T. (1979). Differential atrophy of sensory and motor fibers following section of cat peripheral nerves. Brain Res. 178, 347-361. doi: 10.1016/0006-8993(79)90698-X

Hoke, A., Redett, R., Hameed, H., Jari, R., Zhou, C., Li, Z. B., et al. (2006). Schwann cells express motor and sensory phenotypes that regulate axon regeneration. J. Neurosci. 26, 9646-9655. doi: 10.1523/JNEUROSCI.1620-06.2006

Hong, E. J., McCord, A. E., and Greenberg, M. E. (2008). A biological function for the neuronal activity-dependent component of Bdnf transcription in the development of cortical inhibition. Neuron 60, 610-624. doi: 10.1016/j.neuron.2008.09.024

Huang, E. J., and Reichardt, L. F. (2003). Trk receptors: roles in neuronal signal transduction. Annu. Rev. Biochem. 72, 609-642. doi: 10.1146/annurev.biochem.72.121801.161629

Huang, J., Zhang, Y., Lu, L., Hu, X., and Luo, Z. (2013). Electrical stimulation accelerates nerve regeneration and functional recovery in delayed peripheral nerve injury in rats. Eur. J. Neurosci. 38, 3691-3701. doi: 10.1111/ejn. 12370

Hwang, J. J., Park, M. H., Choi, S. Y., and Koh, J. Y. (2005). Activation of the Trk signaling pathway by extracellular zinc. Role of metalloproteinases. J. Biol. Chem. 280, 11995-12001. doi: 10.1074/jbc.M403172200

Ibáñez, C., and Simi, A. (2012). p75 neurotrophin receptor signaling in nervous system injury and degeneration: paradox and opportunity. Trends Neurosci. 35, 431-440. doi: 10.1016/j.tins.2012.03.007

Ieraci, A., Madaio, A. I., Mallei, A., Lee, F. S., and Popoli, M. (2016). Brainderived neurotrophic factor Val66Met human polymorphism impairs the beneficial exercise-induced neurobiological changes in mice. 41:3070-3079. Neuropsychopharmacology 41, 3070-3079. doi: 10.1038/npp.2016.120

Inagaki, N., and Katsuno, H. (2017). Actin waves: origin of cell polarization and migration? Trends Cell Biol. 27, 515-526. doi: 10.1016/j.tcb.2017.02.003

Jaiswal, P. B., Mistretta, O. C., Ward, P. J., and English, A. W. (2018). Chemogenetic enhancement of axon regeneration following peripheral nerve injury in the SLICK-A mouse. Brain Sci. 8:93. doi: 10.3390/brainsci8050093

Jaiswal, P. B., Tung, J. K., Gross, R. E., and English, A. W. (2017). Motoneuron activity is required for enhancements in functional recovery after peripheral nerve injury in exercised female mice. J. Neurosci. Res. doi: 10.1002/jnr.24109. [Epub ahead of print].

Jankowski, M. P., Cornuet, P. K., McIlwrath, S., Koerber, H. R., and Albers, K. M. (2006). SRY-box containing gene 11 (Sox11) transcription factor is required for neuron survival and neurite growth. Neuroscience 143, 501-514. doi: 10.1016/j.neuroscience.2006.09.010

Johnson, H., Hokfelt, T., and Ulfhake, B. (1999). Expression of p75(NTR), trkB and trkC in nonmanipulated and axotomized motoneurons of aged rats. Brain Res. Mol. Brain Res. 69, 21-34. doi: 10.1016/S0169-328X(99)00068-6

Jones, K. J. (1993). Recovery from facial paralysis following crush injury of the facial nerve in hamsters: differential effects of gender and androgen exposure. Exp. Neurol. 121, 133-138. doi: 10.1006/exnr.1993.1079

Jones, K. R., Farinas, I., Backus, C., and Reichardt, L. F. (1994). Targeted disruption of the BDNF gene perturbs brain and sensory neuron development but not motor neuron development. Cell 76, 989-999. doi: 10.1016/0092-8674(94)90377-8

Keifer, J., Sabirzhanov, B. E., Zheng, Z., Li, W., and Clark, T. G. (2009). Cleavage of proBDNF by a tolloid-like metalloproteinase (tTLL) is required for acquisition of in vitro eyeblink classical conditioning J. Neurosci. 29, 14956-14964. doi: 10.1523/JNEUROSCI.3649-09.2009

Klein, A. B., Williamson, R., Santini, M. A., Clemmensen, C., Ettrup, A., Rios, M., et al. (2011). Blood BDNF concentrations reflect brain-tissue BDNF levels across species. Int. J. Neuropsychopharmacol. 14, 347-353. doi: $10.1017 /$ S1461145710000738

Kobayashi, N. R., Bedard, A. M., Hincke, M. T., and Tetzlaff, W. (1996). Increased expression of BDNF and trkB mRNA in rat facial motoneurons after axotomy. Eur. J. Neurosci. 8, 1018-1029. doi: 10.1111/j.1460-9568.1996.tb01588.x

Koenig, E., Martin, R., Titmus, M., and Sotelo-Silveira, J. R. (2000). Cryptic peripheral ribosomal domains distributed intermittently along mammalian myelinated axons. J. Neurosci. 20, 8390-8400. doi: 10.1523/JNEUROSCI.20-22-08390.2000

Kohara, K., Kitamura, A., Morishima, M., and Tsumoto, T. (2001). Activitydependent transfer of brain-derived neurotrophic factor to postsynaptic neurons. Science 291, 2419-2423. doi: 10.1126/science.1057415

Kolbeck, R., Jungbluth, S., and Barde, Y. A. (1994). Characterisation of neurotrophin dimers and monomers. Eur. J. Biochem. 225, 995-1003. doi: 10.1111/j.1432-1033.1994.0995b.x

Koliatsos, V., Crawford, T., and Price, D. (1991). Axotomy induces nerve growth factor receptor immunoreactivity in spinal motor neurons. Brain Res. 549, 297-304. doi: 10.1016/0006-8993(91)90471-7

Koppes, A. N., Nordberg, A. L., Paolillo, G. M., Goodsell, N. M., Darwish, H. A., Zhang, L., et al. (2014). Electrical stimulation of schwann cells promotes sustained increases in neurite outgrowth. Tissue Eng. Part A 20, 494-506. doi: 10.1089/ten.TEA.2013.0012

Krakowiak, J., Liu, C., Papudesu, C., Ward, P. J., Wilhelm, J. C., and English, A. W. (2015). Neuronal BDNF signaling is necessary for the effects of treadmill exercise on synaptic stripping of axotomized motoneurons. Neural Plast. 2015:392591. doi: 10.1155/2015/392591

Krook-Magnuson, E., Ledri, M., Soltesz, I., and Kokaia, M. (2014). How might novel technologies such as optogenetics lead to better treatments in epilepsy? Adv. Exp. Med. Biol. 813, 319-336. doi: 10.1007/978-94-017-8914 $-1 \_26$

Krueger, F., Pardini, M., Huey, E. D., Raymont, V., Solomon, J., Lipsky, R. H., et al. (2011). The role of the Met66 brain-derived neurotrophic factor allele in the recovery of executive functioning after combat-related traumatic brain injury. J. Neurosci. 31, 598-606. doi: 10.1523/JNEUROSCI.139910.2011

Krystosek, A., and Seeds, N. W. (1981). Plasminogen activator release at the neuronal growth cone. Science 213, 1532-1534. doi: 10.1126/science.7197054 
Kuczewski, N., Porcher, C., Lessmann, V., Medina, I., and Gaiarsa, J. L. (2009). Activity-dependent dendritic release of BDNF and biological consequences. Mol. Neurobiol. 39, 37-49. doi: 10.1007/s12035-009-8050-7

Kujawa, K. A., Emeric, E., and Jones, K. J. (1991). Testosterone differentially regulates the regenerative properties of injured hamster facial motoneurons. J. Neurosci. 11, 3898-3906. doi: 10.1523/JNEUROSCI.11-12-03898.1991

Kujawa, K. A., Kinderman, N. B., and Jones, K. J. (1989). Testosteroneinduced acceleration of recovery from facial paralysis following crush axotomy of the facial nerve in male hamsters. Exp. Neurol. 105, 80-85. doi: 10.1016/0014-4886(89)90174-X

Kujawa, K. A., Tanzer, L., and Jones, K. J. (1995). Inhibition of the accelerative effects of testosterone on hamster facial nerve regeneration by the antiandrogen flutamide. Exp. Neurol. 133, 138-143. doi: 10.1006/exnr.1995.1016

Kuzis, K., Coffin, J. D., and Eckenstein, F. P. (1999). Time course and age dependence of motor neuron death following facial nerve crush injury: role of fibroblast growth factor. Exp. Neurol. 157, 77-87. doi: 10.1006/exnr.1999.7014

Kuzniewska, B., Rejmak, E., Malik, A. R., Jaworski, J., Kaczmarek, L., and Kalita, K. (2013). Brain-derived neurotrophic factor induces matrix metalloproteinase 9 expression in neurons via the serum response factor/c-Fos pathway. Mol. Cell. Biol. 33, 2149-2162. doi: 10.1128/MCB.00008-13

Lal, D., Hetzler, L. T., Sharma, N., Wurster, R. D., Marzo, S. J., Jones, K. J., et al. (2008). Electrical stimulation facilitates rat facial nerve recovery from a crush injury. Otolaryngol. Head Neck Surg. 139, 68-73. doi: 10.1016/j.otohns.2008.04.030

Lau, A. G., Irier, H. A., Gu, J., Tian, D., Ku, L., Liu, G., et al. (2010). Distinct $3^{\prime}$ UTRs differentially regulate activity-dependent translation of brain-derived neurotrophic factor (BDNF). Proc. Natl. Acad. Sci. U.S.A. 107, 15945-15950. doi: 10.1073/pnas.1002929107

Lee, R., Kermani, P., Teng, K. K., and Hempstead, B. L. (2001). Regulation of cell survival by secreted Proneurotrophins. Science 294, 1945-1948. doi: $10.1126 /$ science. 1065057

Leech, K. A., and Hornby, T. G. (2017). High-intensity locomotor exercise increases brain-derived neurotrophic factor in individuals with incomplete spinal cord injury. J. Neurotrauma 34, 1240-1248. doi: 10.1089/neu.2016.4532

Lemos, J. R., Alves, C. R., De Souza, S. B. C., Marsiglia, J. D. C., Silva, M. S. M., Pereira, A. C., et al. (2015). Peripheral vascular reactivity and serum BDNF responses to aerobic training are impaired by the BDNF Val66Met polymorphism. Physiol. Genomics 48, 116-123. doi: 10.1152/physiolgenomics.00086.2015

Lessmann, V., Gottmann, K., and Malcangio, M. (2003). Neurotrophin secretion: current facts and future prospects. Prog. Neurobiol. 69, 341-374. doi: 10.1016/S0301-0082(03)00019-4

Lewin, G. R., and Barde, Y. A. (1996). Physiology of the neurotrophins. Annu. Rev. Neurosci. 19, 289-317. doi: 10.1146/annurev.ne.19.030196.001445

Lewin, S. L., Utley, D. S., Cheng, E. T., Verity, A. N., and Terris, D. J. (1997). Simultaneous treatment with BDNF and CNTF after peripheral nerve transection and repair enhances rate of functional recovery compared with BDNF treatment alone. Laryngoscope 107, 992-999. doi: 10.1097/00005537-199707000-00029

Li, Z., Wu, Y., and Baraban, J. M. (2008). The Translin/Trax RNA binding complex: clues to function in the nervous system. Biochim. Biophys. Acta 1779, 479-485. doi: 10.1016/j.bbagrm.2008.03.008

Liao, C.-F., Yang, T.-Y., Chen, Y.-H., Yao, C.-H., Way, T.-D., and Chen, Y.S. (2017). Effects of swimming exercise on nerve regeneration in a rat sciatic nerve transection model. Biomedicine 7:3. doi: 10.1051/bmdcn/20170 70103

Liepinsh, E., Ilag, L. L., Otting, G., and Ibáñez, C. F. (1997). NMR structure of the death domain of the p75 neurotrophin receptor. EMBO J. 16, 4999-5005. doi: 10.1093/emboj/16.16.4999

Linda, H., Shupliakov, O., Ornung, G., Ottersen, O. P., Storm-Mathisen, J., Risling, M., et al. (2000). Ultrastructural evidence for a preferential elimination of glutamate-immunoreactive synaptic terminals from spinal motoneurons after intramedullary axotomy. J. Comp. Neurol. 425, 10-23. doi: 10.1002/1096-9861(20000911)425:13.3.CO;2-R

Lindsay, R. M. (1988). Nerve growth factors (NGF, BDNF) enhance axonal regeneration but are not required for survival of adult sensory neurons. J. Neurosci. 8, 2394-2405. doi: 10.1523/JNEUROSCI.08-07-02394.1988
Liu, C., Ward, P. J., and English, A. W. (2014). The effects of exercise on synaptic stripping require androgen receptor signaling. PLoS ONE 9:e98633. doi: 10.1371/journal.pone. 0098633

Liu, Q. R., Lu, L., Zhu, X. G., Gong, J. P., Shaham, Y., and Uhl, G. R. (2006). Rodent BDNF genes, novel promoters, novel splice variants, and regulation by cocaine. Brain Res. 1067, 1-12. doi: 10.1016/j.brainres.2005.10.004

Liu, R.-J., Lee, F. S., Li, X.-Y., Bambico, F., Duman, R. S., and Aghajanian, G. K. (2012). Brain-derived neurotrophic factor Val66Met allele impairs basal and ketamine-stimulated synaptogenesis in prefrontal cortex. Biol. Psychiatry 71, 996-1005. doi: 10.1016/j.biopsych.2011.09.030

Ljungberg, C., Novikov, L., Kellerth, J. O., Ebendal, T., and Wiberg, M. (1999). The neurotrophins NGF and NT-3 reduce sensory neuronal loss in adult rat after peripheral nerve lesion. Neurosci. Lett. 262, 29-32. doi: 10.1016/\$0304-3940(99)00040-3

Locksley, R. M., Killeen, N., and Lenardo, M. J. (2001). The TNF and TNF receptor superfamilies: integrating mammalian biology. Cell 104, 487-501. doi: 10.1016/S0092-8674(01)00237-9

Loeb, G. E., Marks, W. B., and Hoffer, J. A. (1987). Cat hindlimb motoneurons during locomotion. IV. Participation in cutaneous reflexes. J. Neurophysiol. 57, 563-573. doi: 10.1152/jn.1987.57.2.563

Lonze, B. E., and Ginty, D. D. (2002). Function and regulation of creb family transcription factors in the nervous system. Neuron 35, 605-623. doi: 10.1016/S0896-6273(02)00828-0

Lou, H., Kim, S. K., Zaitsev, E., Snell, C. R., Lu, B., and Loh, Y. P. (2005). Sorting and activity-dependent secretion of BDNF require interaction of a specific motif with the sorting receptor carboxypeptidase e. Neuron 45, 245-255. doi: $10.1016 /$ j.neuron.2004.12.037

Lu, B., Nagappan, G., and Lu, Y. (2014). "BDNF and synaptic plasticity, cognitive function, and dysfunction," in: Neurotrophic Factors, G. R. Lewin and B. D. Carter. Heidelberg: Springer Berlin Heidelberg.

Lu, B., Pang, P. T., and Woo, N. H. (2005). The yin and yang of neurotrophin action. Nat. Rev. Neurosci. 6, 603-614. doi: 10.1038/nrn1726

Maisonpierre, P. C., Le Beau, M. M., Espinosa, R. III, Ip, N. Y., Belluscio, L., De La Monte, S. M., et al. (1991). Human and rat brain-derived neurotrophic factor and neurotrophin-3: gene structures, distributions, and chromosomal localizations. Genomics 10, 558-568. doi: 10.1016/0888-7543(91)90436-I

Makwana, M., and Raivich, G. (2005). Molecular mechanisms in successful peripheral regeneration. FEBS J. 272, 2628-2638. doi: 10.1111/j.1742-4658.2005.04699.x

Mallei, A., Baj, G., Ieraci, A., Corna, S., Musazzi, L., Lee, F. S., et al. (2015). Expression and dendritic trafficking of BDNF-6 splice variant are impaired in knock-in mice carrying human BDNF Val66Met polymorphism. Int. J. Neuropsychopharmacol. 18:pyv069. doi: 10.1093/ijnp/pyv069

Mar, F. M., Bonni, A., and Sousa, M. M. (2014). Cell intrinsic control of axon regeneration. EMBO Rep. 15, 254-263. doi: 10.1002/embr.201337723

Marqueste, T., Alliez, J.-R., Alluin, O., Jammes, Y., and Decherchi, P. (2004). Neuromuscular rehabilitation by treadmill running or electrical stimulation after peripheral nerve injury and repair. J. Appl. Physiol. 96, 1988-1995. doi: 10.1152/japplphysiol.00775.2003

McGregor, C. (2018). The Effect of the Val66Met BDNF Polymorphism on Axon Regeneration After Peripheral Nerve Injury. Ph.D. Emory University.

Mellios, N., Huang, H.-S., Grigorenko, A., Rogaev, E., and Akbarian, S. (2008). A set of differentially expressed miRNAs, including miR-30a-5p, act as posttranscriptional inhibitors of BDNF in prefrontal cortex. Hum. Mol. Genet. 17, 3030-3042. doi: 10.1093/hmg/ddn201

Meyer, M., Matsuoka, I., Wetmore, C., Olson, L., and Thoenen, H. (1992). Enhanced synthesis of brain-derived neurotrophic factor in the lesioned peripheral nerve: different mechanisms are responsible for the regulation of BDNF and NGF mRNA. J. Cell Biol. 119, 45-54. doi: 10.1083/jcb.119.1.45

Mi, S., Lee, X., Shao, Z., Thill, G., Ji, B., Relton, J., et al. (2004). LINGO-1 is a component of the Nogo-66 receptor/p75 signaling complex. Nat. Neurosci. 7, 221-228. doi: 10.1038/nn1188

Michael, G. J., Averill, S., Nitkunan, A., Rattray, M., Bennett, D. L., Yan, Q., et al. (1997). Nerve growth factor treatment increases brain-derived neurotrophic factor selectively in TrkA-expressing dorsal root ganglion cells and in their central terminations within the spinal cord. J. Neurosci. 17, 8476-8490. doi: 10.1523/JNEUROSCI.17-21-08476.1997 
Michael, G. J., Averill, S., Shortland, P. J., Yan, Q., and Priestley, J. V. (1999). Axotomy results in major changes in BDNF expression by dorsal root ganglion cells: BDNF expression in large trkB and trkC cells, in pericellular baskets, and in projections to deep dorsal horn and dorsal column nuclei. Eur. J. Neurosci. 11, 3539-3551. doi: 10.1046/j.1460-9568.1999.00767.x

Middleton, G., Hamanoue, M., Enokido, Y., Wyatt, S., Pennica, D., Jaffray, E., et al. (2000). Cytokine-induced nuclear factor kappa B activation promotes the survival of developing neurons. J. Cell Biol. 148, 325-332. doi: $10.1083 /$ jcb.148.2.325

Minichiello, L. (2009). TrkB signalling pathways in LTP and learning. Nat. Rev. Neurosci. 10, 850-860. doi: 10.1038/nrn2738

Molteni, R., Zheng, J.-Q., Ying, Z., Gómez-Pinilla, F., and Twiss, J. L. (2004). Voluntary exercise increases axonal regeneration from sensory neurons. Proc. Natl. Acad. Sci. U.S.A. 101, 8473-8478. doi: 10.1073/pnas.0401443101

Mowla, S. J., Farhadi, H. F., Pareek, S., Atwal, J. K., Morris, S. J., Seidah, N. G., et al. (2001). Biosynthesis and post-translational processing of the precursor to brain-derived neurotrophic factor. J. Biol. Chem. 276, 12660-12666. doi: 10.1074/jbc.M008104200

Mowla, S. J., Pareek, S., Farhadi, H. F., Petrecca, K., Fawcett, J. P., Seidah, N. G., et al. (1999). Differential sorting of nerve growth factor and brain-derived neurotrophic factor in hippocampal neurons. J. Neurosci. 19, 2069-2080. doi: 10.1523/JNEUROSCI.19-06-02069.1999

Nagappan, G., Zaitsev, E., Senatorov, V. V., Yang, J., Hempstead, B. L., and $\mathrm{Lu}, \mathrm{B}$. (2009). Control of extracellular cleavage of ProBDNF by high frequency neuronal activity. Proc. Natl. Acad. Sci. U.S.A. 106, 1267-1272. doi: $10.1073 /$ pnas. 0807322106

Nagata, S. (1997). Apoptosis by death factor. Cell 88, 355-365. doi: $10.1016 /$ S0092-8674(00)81874-7

Nascimento, C., Pereira, J., Pires De Andrade, L., Garuffi, M., Ayan, C., Kerr, D., et al. (2015). Physical exercise improves peripheral BDNF levels and cognitive functions in elderly mild cognitive impairment individuals with Different BDNF Val66Met Genotypes. J. Alzheimers. Dis. 43, 81-91. doi: $10.3233 / J A D-140576$

Neves-Pereira, M., Mundo, E., Muglia, P., King, N., Macciardi, F., and Kennedy, J. L. (2002). The brain-derived neurotrophic factor gene confers susceptibility to bipolar disorder: evidence from a family-based association study. Am. J. Hum. Genet. 71, 651-655. doi: 10.1086/342288

Nielsen, M. S., Madsen, P., Christensen, E. I., Nykjaer, A., Gliemann, J., Kasper, D., et al. (2001). The sortilin cytoplasmic tail conveys Golgi-endosome transport and binds the VHS domain of the GGA2 sorting protein. EMBO J. 20, 2180-2190. doi: 10.1093/emboj/20.9.2180

Nix, W. A., and Hopf, H. C. (1983). Electrical stimulation of regenerating nerve and its effect on motor recovery. Brain Res. 272, 21-25. doi: 10.1016/0006-8993(83)90360-8

Notaras, M., Hill, R., and Van Den Buuse, M. (2015). The BDNF gene Val66Met polymorphism as a modifier of psychiatric disorder susceptibility: progress and controversy. Mol. Psychiatry 20, 916-930. doi: 10.1038/mp.2015.27

Nykjaer, A., Lee, R., Teng, K. K., Jansen, P., Madsen, P., Nielsen, M. S., et al. (2004). Sortilin is essential for proNGF-induced neuronal cell death. Nature 427, 843-848. doi: 10.1038/nature02319

Oliveira, A. L. R., Thams, S., Lidman, O., Piehl, F., Hökfelt, T., Kärre, K., et al. (2004). A role for MHC class I molecules in synaptic plasticity and regeneration of neurons after axotomy. Proc. Natl. Acad. Sci. U.S.A. 101, 17843-17848. doi: 10.1073/pnas.0408154101

Osborne, M. C., Verhovshek, T., and Sengelaub, D. R. (2007). Androgen regulates trkB immunolabeling in spinal motoneurons. J. Neurosci. Res. 85, 303-309. doi: $10.1002 /$ jnr.21122

Ottem, E. N., Poort, J. E., Wang, H., Jordan, C. L., and Breedlove, S. M. (2010). Differential expression and regulation of brain-derived neurotrophic factor (BDNF) mRNA isoforms in androgen-sensitive motoneurons of the rat lumbar spinal cord. Mol. Cell. Endocrinol. 328, 40-46. doi: 10.1016/j.mce.2010.07.001

Pagnussat, A. S., Michaelsen, S. M., Achaval, M., Ilha, J., Hermel, E. E. S., Back, F. P., et al. (2012). Effect of skilled and unskilled training on nerve regeneration and functional recovery. Braz. J. Med. Biol. Res. 45, 753-762. doi: 10.1590/S0100-879X2012007500084

Park, J.-S., and Höke, A. (2014). Treadmill exercise induced functional recovery after peripheral nerve repair is associated with increased levels of neurotrophic factors. PLoS ONE 9:e90245. doi: 10.1371/journal.pone.0090245
Park, K. K., Liu, K., Hu, Y., Smith, P. D., Wang, C., Cai, B., et al. (2008). Promoting axon regeneration in the adult CNS by modulation of the PTEN/mTOR pathway. Science 322, 963-966. doi: 10.1126/science.1161566

Park, S., Koppes, R. A., Froriep, U. P., Jia, X., Achyuta, A. K. H., McLaughlin, B. L., et al. (2015). Optogenetic control of nerve growth. Sci. Rep. 5:9669. doi: 10.1038/srep09669

Patapoutian, A., and Reichardt, L. F. (2001). Trk receptors: mediators of neurotrophin action. Curr. Opin. Neurobiol. 11, 272-280. doi: 10.1016/S0959-4388(00)00208-7

Pattabiraman, P. P., Tropea, D., Chiaruttini, C., Tongiorgi, E., Cattaneo, A., and Domenici, L. (2005). Neuronal activity regulates the developmental expression and subcellular localization of cortical BDNF mRNA isoforms in vivo. Mol. Cell. Neurosci. 28, 556-570. doi: 10.1016/j.mcn.2004.11.010

Pockett, S., and Gavin, R. M. (1985). Acceleration of peripheral nerve regeneration after crush injury in rat. Neurosci. Lett. 59, 221-224. doi: 10.1016/0304-3940(85)90203-4

Portincasa, A., Gozzo, G., Parisi, D., Annacontini, L., Campanale, A., Basso, G., et al. (2007). Microsurgical treatment of injury to peripheral nerves in upper and lower limbs: a critical review of the last 8 years. Microsurgery 27, 455-462. doi: 10.1002/micr.20382

Pruunsild, P., Kazantseva, A., Aid, T., Palm, K., and Timmusk, T. (2007). Dissecting the human BDNF locus: bidirectional transcription, complex splicing, and multiple promoters. Genomics 90, 397-406. doi: 10.1016/j.ygeno.2007.05.004

Qin, L., Jing, D., Parauda, S., Carmel, J., Ratan, R. R., Lee, F. S., et al. (2014). An adaptive role for BDNF Val66Met polymorphism in motor recovery in chronic stroke. J. Neurosci. 34, 2493-2502. doi: 10.1523/JNEUROSCI.4140-13.2014

Raivich, G., and Kreutzberg, G. W. (1987). Expression of growth factor receptors in injured nervous tissue. I. Axotomy leads to a shift in the cellular distribution of specific beta-nerve growth factor binding in the injured and regenerating PNS. J. Neurocytol. 16, 689-700. doi: 10.1007/BF01637660

Reichardt, L. F. (2006). Neurotrophin-regulated signalling pathways. Philos. Trans. R. Soc. Lond. B Biol. Sci. 361, 1545-1564. doi: 10.1098/rstb.2006.1894

Rende, M., Giambanco, I., Buratta, M., and Tonali, P. (1995). Axotomy induces a different modulation of both low-affinity nerve growth factor receptor and choline acetyltransferase between adult rat spinal and brainstem motoneurons. J. Comp. Neurol. 363, 249-263. doi: 10.1002/cne.903630207

Ribases, M., Gratacos, M., Armengol, L., De Cid, R., Badia, A., Jimenez, L., et al. (2003). Met66 in the brain-derived neurotrophic factor (BDNF) precursor is associated with anorexia nervosa restrictive type. Mol. Psychiatry 8, 745-751. doi: 10.1038/sj.mp.4001281

Rich, K. M., Luszczynski, J. R., Osborne, P. A., and Johnson, E. M. Jr. (1987). Nerve growth factor protects adult sensory neurons from cell death and atrophy caused by nerve injury. J. Neurocytol. 16, 261-268. doi: 10.1007/BF01795309

Richner, M., Ulrichsen, M., Elmegaard, S. L., Dieu, R., Pallesen, L. T., and Vaegter, C. B. (2014). Peripheral nerve injury modulates neurotrophin signaling in the peripheral and central nervous system. Mol. Neurobiol. 50, 945-970. doi: 10.1007/s12035-014-8706-9

Righi, M., Tongiorgi, E., and Cattaneo, A. (2000). Brain-derived neurotrophic factor (BDNF) induces dendritic targeting of BDNF and tyrosine kinase $\mathrm{B}$ mRNAs in hippocampal neurons through a phosphatidylinositol-3 kinase-dependent pathway. J. Neurosci. 20, 3165-3174. doi: 10.1523/JNEUROSCI.20-09-03165.2000

Rodríguez-Tébar, A., Dechant, G., Götz, R., and Barde, Y. A. (1992). Binding of neurotrophin-3 to its neuronal receptors and interactions with nerve growth factor and brain-derived neurotrophic factor. EMBO J. 11, 917-922. doi: 10.1002/j.1460-2075.1992.tb05130.x

Rostami, E., Krueger, F., Zoubak, S., Dal Monte, O., Raymont, V., Pardini, M., et al. (2011). BDNF polymorphism predicts general intelligence after penetrating traumatic brain injury. PLOS ONE 6:e27389. doi: 10.1371/journal.pone.0 027389

Rotterman, T. M., Nardelli, P., Cope, T. C., and Alvarez, F. J. (2014). Normal distribution of VGLUT1 synapses on spinal motoneuron dendrites and their reorganization after nerve injury. J. Neurosci. 34, 3475-3492. doi: 10.1523/JNEUROSCI.4768-13.2014

Roux, P. P., and Barker, P. A. (2002). Neurotrophin signaling through the p75 neurotrophin receptor. Prog. Neurobiol. 67, 203-233. doi: 10.1016/S0301-0082(02)00016-3 
Sabatier, M. J., and English, A. W. (2015). Pathways mediating activity-induced enhancement of recovery from peripheral nerve injury. Exerc. Sport Sci. Rev. 43, 163-171. doi: 10.1249/JES.0000000000000047

Sabatier, M. J., Redmon, N., Schwartz, G., and English, A. W. (2008). Treadmill training promotes axon regeneration in injured peripheral nerves. Exp. Neurol. 211, 489-493. doi: 10.1016/j.expneurol.2008.02.013

Saika, T., Senba, E., Noguchi, K., Sato, M., Yoshida, S., Kubo, T., et al. (1991). Effects of nerve crush and transection on mRNA levels for nerve growth factor receptor in the rat facial motoneurons. Brain Res. Mol. Brain Res. 9, 157-160. doi: $10.1016 / 0169-328 \mathrm{X}(91) 90142-\mathrm{K}$

Sakata, K., Woo, N. H., Martinowich, K., Greene, J. S., Schloesser, R. J., Shen, L., et al. (2009). Critical role of promoter IV-driven BDNF transcription in GABAergic transmission and synaptic plasticity in the prefrontal cortex. Proc. Natl. Acad. Sci. U.S.A. 106, 5942-5947. doi: 10.1073/pnas.0811 431106

Salerno, K. M., Jing, X., Diges, C. M., Cornuet, P. K., Glorioso, J. C., and Albers, K. M. (2012). Sox11 modulates brain-derived neurotrophic factor expression in an exon promoter-specific manner. J. Neurosci. Res. 90, 1011-1019. doi: 10.1002/jnr.23010

Sarikcioglu, L., and Oguz, N. (2001). Exercise training and axonal regeneration after sciatic nerve injury. Int. J. Neurosci. 109, 173-177. doi: $10.3109 / 00207450108986533$

Schmidt, A., and Hall, A. (2002). Guanine nucleotide exchange factors for Rho Gtpases: turning on the switch. Genes Dev. 16, 1587-1609. doi: $10.1101 /$ gad. 1003302

Scholz, T., Krichevsky, A., Sumarto, A., Jaffurs, D., Wirth, G. A., Paydar, K., et al. (2009). Peripheral nerve injuries: an international survey of current treatments and future perspectives. J. Reconstr. Microsurg. 25, 339-344. doi: 10.1055/s-0029-1215529

Schwartz, P. M., Borghesani, P. R., Levy, R. L., Pomeroy, S. L., and Segal, R. A. (1997). Abnormal cerebellar development and foliation in BDNF-/- mice reveals a role for neurotrophins in CNS patterning. Neuron 19, 269-281. doi: 10.1016/S0896-6273(00)80938-1

Scott, A. L., Borisoff, J. F., and Ramer, M. S. (2005). Deafferentation and neurotrophin-mediated intraspinal sprouting: a central role for the p75 neurotrophin receptor. Eur. J. Neurosci. 21, 81-92. doi: $10.1111 / j .1460-9568.2004 .03838 . x$

Scott, A. L., and Ramer, M. S. (2010). Schwann cell p75NTR prevents spontaneous sensory reinnervation of the adult spinal cord. Brain 133, 421-432. doi: 10.1093/brain/awp316

Seidah, N., Benjannet, S., Pareek, S., Chrétien, M., and Murphy, R. (1996a). Cellular processing of the neurotrophin precursors of NT3 and BDNF by the mammalian proprotein convertases. FEBS Lett. 379, 247-250. doi: 10.1016/0014-5793(95)01520-5

Seidah, N. G., Benjannet, S., Pareek, S., Savaria, D., Hamelin, J., Goulet, B., et al. (1996b). Cellular processing of the nerve growth factor precursor by the mammalian pro-protein convertases. Biochem. J. 314, 951-960. doi: $10.1042 /$ bj3140951

Seo, T. B., Han, I. S., Yoon, J. H., Hong, K. E., Yoon, S. J., and Namgung, U. (2006). Involvement of Cdc2 in axonal regeneration enhanced by exercise training in rats. Med. Sci. Sports Exerc. 38, 1267-1276. doi: 10.1249/01.mss.0000227311.00976.68

Seo, T. B., Oh, M. J., You, B. G., Kwon, K. B., Chang, I. A., Yoon, J. H., et al. (2009). ERK1/2-mediated Schwann cell proliferation in the regenerating sciatic nerve by treadmill training. J. Neurotrauma 26, 1733-1744. doi: $10.1089 /$ neu.2008.0711

Sharma, N., Coughlin, L., Porter, R., Tanzer, L., Wurster, R., Marzo, S., et al. (2009). Effects of electrical stimulation and gonadal steroids on rat facial nerve regenerative properties. Restor. Neurol. Neurosci. 27, 633-644. doi: 10.3233/RNN-2009-0489

Sharma, N., Marzo, S. J., Jones, K. J., and Foecking, E. M. (2010a). Electrical stimulation and testosterone differentially enhance expression of regeneration-associated genes. Exp. Neurol. 223, 183-191. doi: 10.1016/j.expneurol.2009.04.031

Sharma, N., Moeller, C. W., Marzo, S. J., Jones, K. J., and Foecking, E. M. (2010b). Combinatorial treatments enhance recovery following facial nerve crush. Laryngoscope 120, 1523-1530. doi: 10.1002/lary.20997 shen, Y. J., Debellard, M. E., Salzer, J. L., Roder, J., and Filbin, M. T. (1998). Myelin-associated glycoprotein in myelin and expressed by Schwann cells inhibits axonal regeneration and branching. Mol. Cell. Neurosci. 12, 79-91. doi: 10.1006/mcne.1998.0700

Shimizu, E., Hashimoto, K., and Iyo, M. (2004). Ethnic difference of the BDNF 196G/A (val66met) polymorphism frequencies: the possibility to explain ethnic mental traits. Am. J. Med. Genet. B Neuropsychiatr. Genet. 126b, 122-123. doi: $10.1002 /$ ajmg.b.20118

Singh, B., Xu, Q. G., Franz, C. K., Zhang, R., Dalton, C., Gordon, T., et al. (2012). Accelerated axon outgrowth, guidance, and target reinnervation across nerve transection gaps following a brief electrical stimulation paradigm. J. Neurosurg. 116, 498-512. doi: 10.3171/2011.10.JNS11612

Sklar, P., Gabriel, S. B., McInnis, M. G., Bennett, P., Lim, Y., Tsan, G., et al. (2002). Family-based association study of 76 candidate genes in bipolar disorder: $\mathrm{BDNF}$ is a potential risk locus. Brain-derived neutrophic factor. Mol. Psychiatry 7, 579-593. doi: 10.1038/sj.mp.4001058

Sohnchen, J., Grosheva, M., Kiryakova, S., Hubbers, C. U., Sinis, N., Skouras, E., et al. (2010). Recovery of whisking function after manual stimulation of denervated vibrissal muscles requires brain-derived neurotrophic factor and its receptor tyrosine kinase B. Neuroscience 170, 372-380. doi: 10.1016/j.neuroscience.2010.06.053

Sohrabji, F., Miranda, R. C., and Toran-Allerand, C. D. (1995). Identification of a putative estrogen response element in the gene encoding brainderived neurotrophic factor. Proc. Natl. Acad. Sci. U.S.A. 92, 11110-11114. doi: 10.1073/pnas.92.24.11110

Song, X. Y., Zhang, F. H., Zhou, F. H., Zhong, J., and Zhou, X. F. (2009). Deletion of p75NTR impairs regeneration of peripheral nerves in mice. Life Sci. 84, 61-68. doi: 10.1016/j.lfs.2008.10.013

Song, X. Y., Zhou, F. H., Zhong, J. H., Wu, L. L., and Zhou, X. F. (2006). Knockout of p75(NTR) impairs re-myelination of injured sciatic nerve in mice. J. Neurochem. 96, 833-842. doi: 10.1111/j.1471-4159.2005.03564.x

Sotelo-Silveira, J., Crispino, M., Puppo, A., Sotelo, J. R., and Koenig, E. (2008). Myelinated axons contain beta-actin mRNA and ZBP-1 in periaxoplasmic ribosomal plaques and depend on cyclic AMP and F-actin integrity for in vitro translation. J. Neurochem. 104, 545-557. doi: 10.1111/j.1471-4159.2007. 04999.x

Souness, J. E., Aldous, D., and Sargent, C. (2000). Immunosuppressive and antiinflammatory effects of cyclic AMP phosphodiesterase (PDE) type 4 inhibitors. Immunopharmacology 47, 127-162. doi: 10.1016/S0162-3109(00)00185-5

Streppel, M., Azzolin, N., Dohm, S., Guntinas-Lichius, O., Haas, C., Grothe, C., et al. (2002). Focal application of neutralizing antibodies to soluble neurotrophic factors reduces collateral axonal branching after peripheral nerve lesion. Eur. J. Neurosci. 15, 1327-1342. doi: 10.1046/j.1460-9568.2002.01971.x

Struebing, F. L., Wang, J., Li, Y., King, R., Mistretta, O. C., English, A. W., et al. (2017). Differential expression of Sox11 and Bdnf mRNA isoforms in the injured and regenerating nervous systems. Front. Mol. Neurosci. 10:354. doi: 10.3389/fnmol.2017.00354

Sulaiman, O. A., and Gordon, T. (2000). Effects of shortand long-term Schwann cell denervation on peripheral nerve regeneration, myelination, and size. Glia 32, 234-246. doi: 10.1002/1098-1136(200012)32:3<234::AID-GLIA40>3.0.CO;2-3

Szuhany, K. L., Bugatti, M., and Otto, M. W. (2015). A meta-analytic review of the effects of exercise on brain-derived neurotrophic factor. J. Psychiatr. Res. 60, 56-64. doi: 10.1016/j.jpsychires.2014.10.003

Tam, S. L., Archibald, V., Jassar, B., Tyreman, N., and Gordon, T. (2001). Increased neuromuscular activity reduces sprouting in partially denervated muscles. J. Neurosci. 21, 654-667. doi: 10.1523/JNEUROSCI.21-02-00654.2001

Taniuchi, M., Clark, H. B., and Johnson, E. M. (1986). Induction of nerve growth factor receptor in Schwann cells after axotomy. Proc. Natl. Acad. Sci. U.S.A. 83, 4094-4098. doi: 10.1073/pnas.83.11.4094

Tanzer, L., and Jones, K. J. (1997). Gonadal steroid regulation of hamster facial nerve regeneration: effects of dihydrotestosterone and estradiol. Exp. Neurol. 146, 258-264. doi: 10.1006/exnr.1997.6529

Tao, X., Finkbeiner, S., Arnold, D. B., Shaywitz, A. J., and Greenberg, M. E. (1998). Ca2+ influx regulates BDNF transcription by a CREB family transcription factor-dependent mechanism. Neuron 20, 709-726. doi: $10.1016 /$ S0896-6273(00)81010-7 
Teng, H. K., Teng, K. K., Lee, R., Wright, S., Tevar, S., Almeida, R. D., et al. (2005). ProBDNF induces neuronal apoptosis via activation of a receptor complex of p75NTR and sortilin. J. Neurosci. 25, 5455-5463. doi: 10.1523/JNEUROSCI.5123-04.2005

Teodori, R. M., Betini, J., De Oliveira, L. S., Sobral, L. L., Takeda, S. Y. M., and Montebelo, M. I. D. L. (2011). Swimming exercise in the acute or late phase after sciatic nerve crush accelerates nerve regeneration. Neural Plast. 2011:783901. doi: 10.1155/2011/783901

Thompson, N. J., Sengelaub, D. R., and English, A. W. (2013). Enhancement of peripheral nerve regeneration due to treadmill training and electrical stimulation is dependent on androgen receptor signaling. Dev. Neurobiol. 74, 531-540. doi: 10.1002/dneu.22147

Timmusk, T., Palm, K., Metsis, M., Reintam, T., Paalme, V., Saarma, M., et al. (1993). Multiple promoters direct tissue-specific expression of the rat BDNF gene. Neuron 10, 475-489. doi: 10.1016/0896-6273(93)9 $0335-\mathrm{O}$

Tomita, K., Kubo, T., Matsuda, K., Fujiwara, T., Yano, K., Winograd, J. M., et al. (2007). The neurotrophin receptor p75NTR in Schwann cells is implicated in remyelination and motor recovery after peripheral nerve injury. Glia 55 , 1199-1208. doi: 10.1002/glia.20533

Tongiorgi, E., Righi, M., and Cattaneo, A. (1997). Activity-Dependent dendritic targeting of BDNF and TrkB mRNAs in hippocampal neurons. J. Neurosci. 17, 9492-9505. doi: 10.1523/JNEUROSCI.17-24-09492.1997

Udina, E., Cobianchi, S., Allodi, I., and Navarro, X. (2011a). Effects of activitydependent strategies on regeneration and plasticity after peripheral nerve injuries. Ann. Anat. 193, 347-353. doi: 10.1016/j.aanat.2011. 02.012

Udina, E., Ladak, A., Furey, M., Brushart, T., Tyreman, N., and Gordon, T. (2010). Rolipram-induced elevation of cAMP or chondroitinase ABC breakdown of inhibitory proteoglycans in the extracellular matrix promotes peripheral nerve regeneration. Exp. Neurol. 223, 143-152. doi: 10.1016/j.expneurol.2009. 08.026

Udina, E., Puigdemasa, A., and Navarro, X. (2011b). Passive and active exercise improve regeneration and muscle reinnervation after peripheral nerve injury in the rat. Muscle Nerve 43, 500-509. doi: 10.1002/mus. 21912

Uegaki, K., Kumanogoh, H., Mizui, T., Hirokawa, T., Ishikawa, Y., and Kojima, M. (2017). Bdnf binds its pro-peptide with high affinity and the common Val66Met polymorphism attenuates the interaction. Int. J. Mol. Sci. 18:E1042. doi: 10.3390/ijms18051042

Vaghi, V., Polacchini, A., Baj, G., Pinheiro, V. L. M., Vicario, A., and Tongiorgi, E. (2014). Pharmacological profile of brain-derived neurotrophic factor (BDNF) splice variant translation using a novel drug screening assay: a "quantitative code". J. Biol. Chem. 289, 27702-27713. doi: 10.1074/jbc.M114.5 86719

van Meeteren, N. L., Brakkee, J. H., Hamers, F. P., Helders, P. J., and Gispen, W. H. (1997). Exercise training improves functional recovery and motor nerve conduction velocity after sciatic nerve crush lesion in the rat. Arch. Phys. Med. Rehabil. 78, 70-77. doi: 10.1016/S0003-9993(97)90013-7

van Meeteren, N. L., Brakkee, J. H., Helders, P. J., and Gispen, W. H. (1998). The effect of exercise training on functional recovery after sciatic nerve crush in the rat. J. Peripher. Nerv. Syst. 3, 277-282.

Varendi, K., Kumar, A., Härma, M.-A., and Andressoo, J.-O. (2014). miR-1, miR10b, miR-155, and miR-191 are novel regulators of BDNF. Cell. Mol. Life Sci. 71, 4443-4456. doi: 10.1007/s00018-014-1628-x

Verhovshek, T., Cai, Y., Osborne, M. C., and Sengelaub, D. R. (2010). Androgen regulates brain-derived neurotrophic factor in spinal motoneurons and their target musculature. Endocrinology 151, 253-261. doi: 10.1210/en.200 9-1036

Vicario, A., Colliva, A., Ratti, A., Davidovic, L., Baj, G., Gricman, Ł., et al. (2015). Dendritic targeting of short and long $3^{\prime}$ UTR BDNF mRNA is regulated by BDNF or NT-3 and distinct sets of RNA-binding proteins. Front. Mol. Neurosci. 8:62. doi: $10.3389 /$ fnmol.2015.00062

Vivo, M., Puigdemasa, A., Casals, L., Asensio, E., Udina, E., and Navarro, X. (2008). Immediate electrical stimulation enhances regeneration and reinnervation and modulates spinal plastic changes after sciatic nerve injury and repair. Exp. Neurol. 211, 180-193. doi: 10.1016/j.expneurol.2008. 01.020
Walsh, G. S., Krol, K. M., Crutcher, K. A., and Kawaja, M. D. (1999). Enhanced neurotrophin-induced axon growth in myelinated portions of the CNS in mice lacking the p75 neurotrophin receptor. J. Neurosci. 19, 4155-4168. doi: 10.1523/JNEUROSCI.19-10-04155.1999

Wan, L., Xia, R., and Ding, W. (2010). Short-term low-frequency electrical stimulation enhanced remyelination of injured peripheral nerves by inducing the promyelination effect of brain-derived neurotrophic factor on Schwann cell polarization. J. Neurosci. Res. 88, 2578-2587. doi: 10.1002/jnr. 22426

Wang, K. C., Kim, J. A., Sivasankaran, R., Segal, R., and He, Z. (2002). P75 interacts with the Nogo receptor as a co-receptor for Nogo, MAG and OMgp. Nature 420, 74-78. doi: 10.1038/nature01176

Ward, P. J., Clanton, S. L., and English, A. W. (2018). Optogenetically enhanced axon regeneration: motor versus sensory neuron-specific stimulation. Eur. J. Neurosci. 47, 294-304. doi: 10.1111/ejn.13836

Ward, P. J., Jones, L. N., Mulligan, A., Goolsby, W., Wilhelm, J. C., and English, A. W. (2016). Optically-induced neuronal activity is sufficient to promote functional motor axon regeneration in vivo. PLoS ONE 11:e0154243. doi: 10.1371/journal.pone. 0154243

Welin, D., Novikova, L. N., Wiberg, M., Kellerth, J. O., and Novikov, L. N. (2008). Survival and regeneration of cutaneous and muscular afferent neurons after peripheral nerve injury in adult rats. Exp. Brain Res. 186, 315-323. doi: 10.1007/s00221-007-1232-5

West, A. E., Chen, W. G., Dalva, M. B., Dolmetsch, R. E., Kornhauser, J. M., Shaywitz, A. J., et al. (2001). Calcium regulation of neuronal gene expression. Proc. Natl. Acad. Sci. U.S.A. 98, 11024-11031. doi: 10.1073/pnas.1913 52298

White, D. M., Walker, S., Brenneman, D. E., and Gozes, I. (2000). CREB contributes to the increased neurite outgrowth of sensory neurons induced by vasoactive intestinal polypeptide and activity-dependent neurotrophic factor. Brain Res. 868, 31-38. doi: 10.1016/S0006-8993(00)02259-9

Wiberg, R., Novikova, L. N., and Kingham, P. J. (2018). Evaluation of apoptotic pathways in dorsal root ganglion neurons following peripheral nerve injury. Neuroreport 29, 779-785. doi: 10.1097/WNR.00000000000 01031

Wilhelm, J., Xu, M., Cucoranu, D., Chmielewski, S., Holmes, T., Lau, K., et al. (2012). Cooperative roles of BDNF expression in neurons and Schwann cells are modulated by exercise to facilitate nerve regeneration. J. Neurosci. 32, 5002-5009. doi: 10.1523/JNEUROSCI.141111.2012

Willis, D. E., Xu, M., Donnelly, C. J., Tep, C., Kendall, M., Erenstheyn, M., et al. (2011). Axonal localization of transgene mRNA in mature PNS and CNS neurons. J. Neurosci. 31, 14481-14487. doi: 10.1523/JNEUROSCI.295011.2011

Wong, J. N., Olson, J. L., Morhart, M. J., and Chan, K. M. (2015). Electrical stimulation enhances sensory recovery: a randomized controlled trial. Ann. Neurol. 77, 996-1006. doi: 10.1002/ana.24397

Wood, K., Wilhelm, J., Sabatier, M., Liu, K., Gu, J., and English, A. (2012). Sex differences in the effectiveness of treadmill training in enhancing axon regeneration in injured peripheral nerves. Dev. Neurobiol. 72, 688-698. doi: 10.1002/dneu.20960

Wyatt, S., Shooter, E. M., and Davies, A. M. (1990). Expression of the NGF receptor gene in sensory neurons and their cutaneous targets prior to and during innervation. Neuron 4, 421-427. doi: 10.1016/0896-6273(90)90 054-J

Yamashita, T., Tucker, K. L., and Barde, Y. A. (1999). Neurotrophin binding to the p75 receptor modulates Rho activity and axonal outgrowth. Neuron 24, 585-593. doi: 10.1016/S0896-6273(00)81114-9

Yan, Q., and Johnson, E. (1988). An immunohistochemical study of the nerve growth factor receptor in developing rats. J. Neurosci. 8, 3481-3498. doi: 10.1523/JNEUROSCI.08-09-03481.1988

Yang, F., Je, H. S., Ji, Y., Nagappan, G., Hempstead, B., and Lu, B. (2009). Pro-BDNF-induced synaptic depression and retraction at developing neuromuscular synapses. J. Cell Biol. 185, 727-741. doi: 10.1083/jcb.200811147

Yao, J., Sasaki, Y., Wen, Z., Bassell, G. J., and Zheng, J. Q. (2006). An essential role for $\beta$-actin mRNA localization and translation in $\mathrm{Ca}^{2+}$. dependent growth cone guidance. Nat. Neurosci. 9, 1265-1273. doi: 10.1038/n n1773 
Zhang, F. H., Huang, P., Yang, P. S., and Zhang, X. (2010). Influence of p75 neurotrophin receptor knockout on the regeneration of facial nerves after crush injury in mouse. Hua Xi Kou Qiang Yi Xue Za Zhi 28, 95-98.

Zhang, J. Y., Luo, X. G., Xian Cory, J., Liu, Z. H., and Zhou, X. F. (2008). Endogenous BDNF is required for myelination and regeneration of injured sciatic nerve in rodents. Eur. J. Neurosci. 12, 4171-4180. doi: 10.1111/j.1460-9568.2000.01312.x

Zhou, X. F., Li, W. P., Zhou, F. H., Zhong, J. H., Mi, J. X., Wu, L. L., et al. (2005). Differential effects of endogenous brain-derived neurotrophic factor on the survival of axotomized sensory neurons in dorsal root ganglia: a possible role for the p75 neurotrophin receptor. Neuroscience 132, 591-603. doi: 10.1016/j.neuroscience.2004.12.034

Zhou, X. F., Rush, R. A., and McLachlan, E. M. (1996). Differential expression of the p75 nerve growth factor receptor in glia and neurons of the rat dorsal root ganglia after peripheral nerve transection. J. Neurosci. 16, 2901-2911. doi: 10.1523/JNEUROSCI.16-09-0290 1.1996

Conflict of Interest Statement: The authors declare that the research was conducted in the absence of any commercial or financial relationships that could be construed as a potential conflict of interest.

Copyright (C) 2019 McGregor and English. This is an open-access article distributed under the terms of the Creative Commons Attribution License (CC BY). The use, distribution or reproduction in other forums is permitted, provided the original author(s) and the copyright owner(s) are credited and that the original publication in this journal is cited, in accordance with accepted academic practice. No use, distribution or reproduction is permitted which does not comply with these terms. 